University of Louisville

ThinkIR: The University of Louisville's Institutional Repository

$5-2010$

\title{
"Still I rise!" Public discourse surrounding the development of public schools for African Americans in Louisville, Kentucky, 1862-1872.
}

Michelle Bachelor Robinson

University of Louisville

Follow this and additional works at: https://ir.library.louisville.edu/etd

\section{Recommended Citation}

Robinson, Michelle Bachelor, "'Still I rise!" Public discourse surrounding the development of public schools for African Americans in Louisville, Kentucky, 1862--1872." (2010). Electronic Theses and Dissertations. Paper 1217.

https://doi.org/10.18297/etd/1217

This Doctoral Dissertation is brought to you for free and open access by ThinkIR: The University of Louisville's Institutional Repository. It has been accepted for inclusion in Electronic Theses and Dissertations by an authorized administrator of ThinkIR: The University of Louisville's Institutional Repository. This title appears here courtesy of the author, who has retained all other copyrights. For more information, please contact thinkir@louisville.edu. 


\title{
"STILL I RISE!" PUBLIC DISCOURSE SURROUNDING THE DEVELOPMENT OF PUBLIC SCHOOLS FOR AFRICAN AMERICANS IN LOUISVILLE, KENTUCKY, 1862-1872
}

\author{
By \\ Michelle Bachelor Robinson \\ B.A., Cameron University, 1994 \\ M.A., University of Louisville, 2005

\begin{abstract}
A Dissertation
Submitted to the Faculty of the

College of Arts and Sciences of the University of Louisville

In Partial Fulfillment of the Requirements

For the Degree of
\end{abstract}

Doctor of Philosophy

Department of English

University of Louisville

Louisville, Kentucky

May 2010 
Copyright 2010 by Michelle Bachelor Robinson

All rights reserved 
"STILL I RISE!" PUBLIC DISCOURSE SURROUNDING THE DEVELOPMENT OF PUBLIC SCHOOLS FOR AFRICAN AMERICANS

IN LOUISVILLE, KENTUCKY 1862-1872

By

Michelle Bachelor Robinson

B.A., Cameron University, 1994

M.A., University of Louisville, 2005

A Dissertation Approved on

March 3, 2005

by the following Dissertation Committee:

Dr. J. Carol Mattingly

Dean J. Blaine Hudson

Dr. David Anderson

Dr. Dennis Hall

Dr. Susan Ryan 


\section{DEDICATION}

I dedicate my dissertation, first and foremost, to my husband Michael Allen Robinson who has been my love, my partner, my collaborator, my colleague, and my friend, but most of all, he has been my ever present reminder of why we took this journey together and where it would ultimately lead.

I also dedicate this work to my sons, Alvin, Joshua, and Caleb Miller whose lives drastically changed as a result of my journey; yet, they never failed to tell me how proud they were of my accomplishments. 


\section{ACKNOWLEDGEMENTS}

This dissertation makes much of Deborah Brandt's concept of literacy sponsorship, so when reflecting on my academic achievements, I fondly remember those who have sponsored my efforts on this lifelong journey. I thank my mother Beverly Bachelor Moss who modeled for me the strength and fortitude of a strong AfricanAmerican woman and demonstrated what it meant to be a lifelong learner. I thank my grandparents, Jacob and Mildred Bachelor, who were my first sponsors, rewarding my academic performance and encouraging me to stay in school. I thank my aunt, Jacqueline Bachelor, who helped me maintain my domestic life amid teaching courses, researching in the archives, writing the dissertation, and attending academic conferences.

Of course, there are always those who are not biological family members, but certainly qualify as academic family members. First, I thank my chair, mentor, and friend Dr. J. Carol Mattingly who managed to keep a contagious enthusiasm about my work over a period of two years when I was struggling and my own energy was waning and who also served as a companion and guide through every bit of every part of my graduate work experience. I thank my dissertation group members: Dr. Anca Iancu, who was here in the beginning to help me conceptualize my argument; Dr. Phillip Blackmon, who offered valuable critique and emotional support until the bitter end; and Allison Egnew Smith who has been my friend, confidante, and objective reader throughout the entire graduate program. I thank my mentor and teacher Dr. Dale Billingsley, Vice Provost of Undergraduate Affairs, who found a special and unusual place for me in academia, a 
place where I served on multiple university-wide committees and interacted with administrative teams that helped shape my academic identity. Dr. Billingsley modeled professionalism, nurtured my confidence, and cultivated an atmosphere that allowed me to pursue my dream and provided the means by which it could be done-words are just not enough!

Finally, I thank Dr. Beth Boehm for her diligence in finding a place for me in the University of Louisville master's program seven years ago and for demonstrating what I respect most in great teaching and mentoring. I thank Dr. Debra Journet who pulled me aside in the first year of my master's program and told me I had the tenacity to take my academic pursuits to the next level. I thank my dean and mentor Dr. J. Blaine Hudson whose weekly meetings in the homestretch of this project helped me to shape the Louisville chapter which was at the core of this work. I thank my committee members: Dr. David Anderson for his cheerleading as I waded through research, writing, and job market anxiety; Dr. Dennis Hall for his willingness, careful reading, and response to my text, and Dr. Susan Ryan first for her tireless efforts in preparing my application for the Southern Region Educational Board Doctoral Fellowship (SREB - without which this work would not have been possible) and also for her attention to detail and suggestions for future research. I thank Dr. Ansley Abraham for taking care of all SREB scholars but especially for always being there for me, and I thank Dr. Michael Cuyjet for his mentorship and support both at the University of Louisville and through the SREB network. 


\section{ABSTRACT \\ “STILL I RISE!” PUBLIC DISCOURSE SURROUNDING THE DEVELOPMENT OF PUBLIC SCHOOLS FOR AFRICAN AMERICANS IN LOUISVILLE, KENTUCKY 1862-1872

\author{
Michelle Bachelor Robinson
}

March 3, 2010

I conducted my dissertation research in the national, state, and local archives. Using Deborah Brandt's "Sponsors of Literacy" as a conceptual framework and Critical Race Theory as a theoretical framework, I offer Louisville, Kentucky as a historical case study for how an established and empowered community of free blacks can serve as a catalyst to bring about social and political change through the acquisition of literacy.

This dissertation is divided into four chapters. Chapter One explains the scholarly context of my dissertation. I argue that post-emancipation African Americans had a sense of urgency for the acquisition of literacy, and that they were their own primary sponsors. Finally, I offer a review of the limited literature in this research area, an overview of my scholarly position, and a summary of the overall dissertation. Chapter Two contextualizes the development of African-American schools in Louisville, Kentucky. I offer a history of the emergence of public schools nationwide as a tool of assimilation. I also offer a discussion of Kentucky state legislative activity that hindered funding and postponed the opening of public schools for African Americans for more than 4 years statewide. I discuss ways in which rhetorical practices were used to victimize African-Americans who developed a funding plan to support schools for their own children while also contributing tax dollars to majority schools. 
Chapter Three offers Louisville as a historic case study. I argue that Louisville was a place with a unique set of circumstances that allowed for the development of an atypical African-American community. I argue that the acquisition of literacy permitted African-Americans in this community to exercise agency that spurred socio-economic change. I also argue that the newspaper was a powerful source of agency, and I juxtapose the self-report system in African-American newspapers with reports of African-American community activities in the publications of the majority. Finally, Chapter Four considers ways that this narrative contributes to scholarship in African-American studies, AfricanAmerican literacy, African-African rhetoric, Rhetoric and Composition, and to some degree pedagogical practice. 


\section{TABLE OF CONTENTS}

PAGE

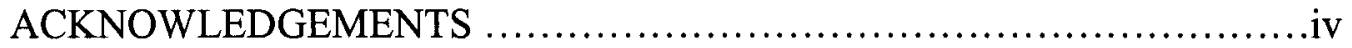

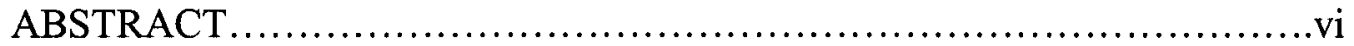

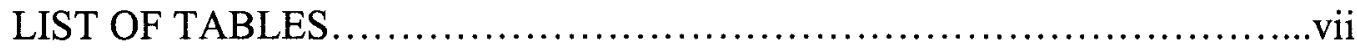

CHAPTER ONE: Life, Liberty and the Pursuit of Literacy $\ldots . \ldots \ldots \ldots \ldots \ldots \ldots . . . . .1$

"History in the Spaces Left"....................................... 1

African-American Histories................................. 1

Nineteenth-Century African-American Literacy.....................2

Slave Literacy............................................

The Sense of Urgency.......................................4

Literacy as Political, Economic, and Social Progress.............6

Limitations of Other Resources for Upward Mobility...........8

The Utility of Literacy............................................ 9

Political and Social Reform................................ 9

Role in Establishment of Community.................... 10

Sponsorship.................................................... 11

Self-Sponsorship - The State of Kentucky.................... 13

Louisville, Kentucky: Context for a Case Study.......................14

Louisville, Kentucky: A Unique Place with a Unique Set of Circumstances....................14

Studies of African-American Literacy and Histories of African-American Schools..................14

Archival Discovery and Valuable Sources.......................... 19

My Scholarly Position....................................19

In Search of Lost Histories...................................21

Limitations of Historical/Archival Research.................23

Primary Sources............................................24

Secondary Sources.......................................25

Research Questions......................................26

Description of Chapters.........................................27

CHAPTERTWO: From Literacy Learning to Formal Education:

The History of African-American Schools...............29

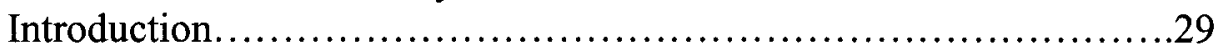

The Conditions of Reconstruction..............................29

Post-War Economy..........................................29

The Republican Agenda.....................................30

viii 
The Push for Public Schools: A Tool for Assimilation............... 31

National Conversations about Public Schools

for African Americans............................... 32

Freedmen Bureau Agenda and Papers...................... 32

State Conversations about Public Schools

For African Americans................................. 35

Kentucky State Laws Passed.................................. 37

Critical Race Theory .....................................45

Problems Establishing Public Schools for the Majority.......... 49

Kentucky Colored Educational Conventions....................51

Educational Rhetoric.......................................55

The African-American Press...................................59

Self-Help as Self-Sponsorship...........................61

CHAPTER THREE: Making the Case for Louisville, Kentucky:

A Unique Set of Circumstance............................ 62

Introduction.................................................. 62

The Cultural Landscape Yields the Discourse Community...... 63

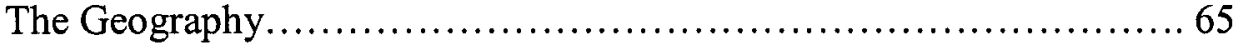

The River................................................ 65

The Economy............................................ 65

The Ante-Bellum African-American Community...................... 67

Slavery in Louisville....................................... 67

Ante-Bellum African-American Churches....................71

Ante-Bellum African-American Schools......................... 73

Wartime Louisville..........................................74

African-American Leaders...................................76

Exercises in Agency and Absence.................................. 78

Competing Discourses........................................ 80

A Commitment to Literacy in Louisville.................................884

African-American Public Schools:

The End of a Long Battle............................85

The Climate and Structure for Cultural Interaction............... 87

Conclusion.......................................................... 89

CHAPTER FOUR: That was Then, This is Now:

Implications of a Historical Case Study ......................91

History Meets Modernity.........................................91

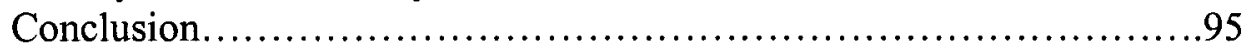

Implications...............................................97

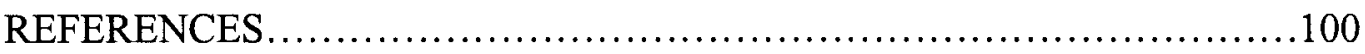

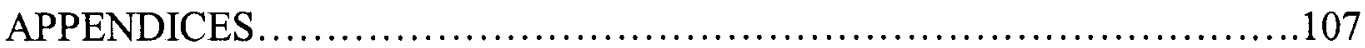

CURRICULUM VITAE .................................................111 


\section{LIST OF TABLES}

TABLE

PAGE

1. Kentucky African-American Literacy Rates..............................35

2. Kentucky Literacy Rate for reading and Writing............................36

3. Population of African Americans in

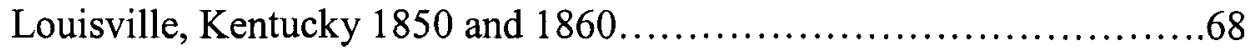




\section{CHAPTER ONE}

\section{Life, Liberty, and the Pursuit of Literacy}

"Revisionist history reexamines America's historical record, replacing comforting majoritarian interpretations of events with ones that square more accurately with minorities' experiences."

(Delgado and Stefancic 20)

\section{1. "History in the Spaces Left"}

African-American Histories

The Civil War served as a bittersweet experience in American history. Though it destroyed more lives than any other war in the history of this country, it served as a mechanism of liberation for the African American slave. The onset and aftermath of the Civil War brought about many changes in the lives of the African-American masses. At the end of the Civil War, African Americans were hopeful that they had arrived at the end of a long journey to freedom only to find that the journey for literacy had only just begun. This study is the retelling of one such journey: the African-American pursuit of literacy in Louisville, Kentucky 1860-1873.

Critical Race Theorists remind us, as in the epigraph above, that marginalized histories are worthy of recovery and retelling, especially from the perspective of the marginalized. The works of Jacqueline Jones Royster and Shirley Wilson Logan attest to the many nineteenth-century narratives of African-American literacy yet to be told. Both Royster and Jean C. Williams attempt to fill in "History in Spaces Left" as they offer an extensive history of African Americans in higher education, and Keith Gilyard hopes to "spur some impassioned archival research" with his "African American Contributions to 
Composition Studies" (1999). These explorations are a small percentage of the vast number of recovered literacy narratives available in the field of Rhetoric and Composition, and this study seeks to contribute to this growing body of knowledge by offering Louisville as a historical case study that examines the acquisition of literacy in an African-American, border state community - a unique space.

\section{Nineteenth-Century African-American Literacy}

\section{Slave Literacy}

In order to truly understand the pursuit of literacy among African Americans in the nineteenth century, one must first understand the attitude of most nineteenth-century African Americans toward literacy. During slavery, as many slave narratives have substantiated, acquiring the ability to read and write was the secret mission of many slaves. Literacy was the initial step to liberation-liberate the mind and the body would follow; however, the acquisition of literacy for African Americans, both free and enslaved, usually came at great costs. Both the teacher and student stood a chance to be physically, and in some cases legally, reprimanded. As Janet Cornelius states in her account of Thomas Johnson's story in When I Can Read My Title Clear: Literacy, Slavery, and Religion in the Antebellum South (1991), the analysis of slave narratives "makes clear how and why reading and writing were so important to some slaves that they would risk death or mutilation to achieve them. . . reading and writing, above all, pointed the way to freedom - first of all in the mind and spirit, and often in the body" (61). In the mind of the slave, literacy provided a means by which to obtain freedom. Literacy enabled the enslaved to more successfully negotiate his or her hostile environment and strategize about ways to ultimately secure freedom in the future. 
Therefore, many slaves through various strategies, even sometimes trickery, went to great measures to situate themselves in creative learning environments to secure literacy.

Some instruction was certainly consensual. White sponsors were willing to take risks in teaching slaves to read and write, and other times, slaves eavesdropped on the literacy learning of their masters' and mistresses' children or tricked them into sharing their knowledge. Slaves pretended to dote on their masters' children, or as in the case of Frederick Douglass, children outside the plantation, while getting them to repeat their lessons to them. In situations where both parties were invested in the literacy learning of the slave, both parties understood the tremendous risks involved in these secret pursuits of literacy, as Cornelius states:

Whites were reluctant to teach openly and seldom bragged in print about teaching slaves; where laws were not a discouragement, custom was, and slave narratives include stories of whites who were punished for going against the community's wishes. More common in slave accounts was the knowledge of grim punishments meted out to literate slaves. These deterred some slaves from learning or at least taught them to keep their learning to themselves. (62)

Acquiring literacy was like mining for precious jewels; there were many risks involved, but most slaves (as well as many of their white sponsors) felt as though the reward was well worth the risks (Cornelius, Logan, Royster, Williams).

Analyses of these personal and cultural literacy narratives provide snapshots of African-American interactions with literacy in the nineteenth century prior to emancipation. One way to surely spur a group of people, especially a marginalized group, 
into complete commitment to the acquisition of anything is to tell them that they cannot have it. African-American slaves and freed men and women recognized that the rationale for withholding literacy from them was predisposed by the notion that slaves would become unmanageable in the acts of servitude, so it was in their best interest, given their station in life, as well as the best interests of the slaveholding culture to keep them illiterate. Royster states in Traces of a Stream: Literacy and Social Change among African American Women (2000), "in order to maintain the levels of obedience many slaveholders felt necessary, several states established laws that prohibited the teaching of slaves to read and write, skills which these lawmakers thought would contribute to discontent, disorder, and insurrection" (126). Before the political and social changes that occurred by 1865 , the acquisition of literacy was accomplished at great risk; yet, the works of Cornelius, Royster, and ultimately Williams demonstrate that the hunger for literacy existed in African-American culture despite peril. However, once pursuits of literacy were legitimized by the passing of legislation, African Americans developed a particular sense of urgency for their pursuits.

The Sense of Urgency

When the Civil War came to a close, the Emancipation Proclamation had taken effect, and ultimately the $13^{\text {th }}$ Amendment was passed, African Americans throughout the states felt a particular sense of urgency for the acquisition of literacy. As Heather Andrea Williams points out in Self-Taught: African American Education in Slavery and Freedom (2005), "even as they risked everything to reach freedom, African Americans' once secret acquisition of literacy emerged as both public demand and support for education" (30). After the war, African Americans were openly engaged in literacy learning. Throughout 
the United States in the late nineteenth century, there are many public accounts of African Americans' unsuppressed zeal for literacy because they understood that learning (in particular formal schooling) was essential to their pursuit of true liberation from oppression as well as the acquisition of social equality. Newly freed blacks were committed to making tremendous sacrifices to secure and ensure the education for themselves and their children because they believed in what Harvey J. Graff has called the "literacy myth," that literacy learning would secure social equality (56). '

The acquisition of literacy became the focal point of many African Americans because, after the war, they dreamed of upward mobility and social equality just as they had previously dreamed of freedom. Literacy had been withheld from African Americans, even to the extent that some states made it illegal to teach slaves and free blacks to read and write. Literacy was a possession that many whites had and one from which most African Americans had been guarded. In the minds of many African Americans, literacy was associated with whiteness; therefore, to possess it, would put African Americans on the same level as whites, theoretically. In Self-Taught, Williams' account of William Davis, a contraband ${ }^{2}$ at Fortress Monroe, is demonstrative of the zeal with which African Americans sought literacy. Williams cites a January 1862 issue of the New York Times in which Davis, who traveled to New York to seek support for the freedpeople and to pressure the government for better treatment, describes the eagerness

\footnotetext{
${ }^{1}$ Graff's watershed text, The Literacy Myth: Cultural Integration and Social Structure in the Nineteenth Century, offers an analysis of literacy in $19^{\text {th }}$-century Ontario, Canada, with comparative analyses of Hamilton, London, and Kingston. Graff argues that literacy is inextricably linked to class, and more often than not, the acquisition of literacy does not improve one's socio-economic status.

${ }^{2}$ contraband- a slave who during the American Civil War escaped to or was brought within the Union lines.
} 
with which the contraband children were engaged in literacy learning and states that some truly believed "they were getting white" (41). Even in the minds of children, literacy was associated with whiteness and therefore success. The more they learned the whiter they felt. Williams takes this argument a bit further with the claim that many slave children witnessed the slaveholders' children's literacy transformations. Young people would begin their education in a household learning environment; later, they would go off to college and return to take their places in the "white gentry." Poor whites and blacks got no schooling and remained "poor and powerless" (42). Williams goes on to argue that this phenomenon influenced a correlation between literacy and power, and consequently, "at emancipation, many freedpeople were anxious for education precisely because of its direct relationship to power within society" (42). With the oppression of slavery still in the forefront of their experiences, newly freed African Americans realized the need to acquire literacy. Though change would be a process far too slow, African Americans understood that social and political change would only occur through educating themselves, as they had no other means for upward mobility but literacy.

Literacy as Political, Economic, and Social Progress

One reason for this sense of urgency felt by African Americans was that they viewed literacy to be a means by which to gain political, economic and social progress. Though freedom had been granted by the United States government, the status of African Americans had really not been significantly altered. Many were not prepared to perform intellectual work. In order to rise above the status of servitude and manual labor, African Americans of all ages committed to literacy learning. As Royster describes, in Traces of a Stream, the reception of literacy from the post-Civil War, African-American community 
was like "manna from heaven" (155). She argues that "African Americans understood the implications of literacy and learning in political, economic, and social progress" (123). Literacy became a means by which African Americans could alter their current status, so most were eager to commit. Consequently, schools were overrun with students of all ages eager to change their stations in life.

Beyond the desire to better their current circumstances, African Americans committed to literacy and learning simply because they could. It was human nature at work. One way to create a burning desire for something in a person is to enact severe measures to prevent their having it. African Americans were exercising their right to literacy and learning, a right that had hence been denied; thus, literacy became a political statement as well as an act of independent growth. Royster's Soldiers of Light and Love: Northern Teachers and Georgia Blacks 1865-1873 (1980) also reports on the "urgency" phenomenon: "After emancipation, going to school became a political act as well as a means of personal edification. Black people joined together to establish schools and hire teachers for old and young alike, and their collective efforts represented both defiance to white authority and an expression of community self-interest"(3). Educating oneself was not only an effort at increasing self-esteem or self-worth, but it was to some extent resistance to white authority and an effort to redefine the African American identity as one that included literacy.

African Americans understood the importance of acquiring literacy, and they also understood the problems associated with expecting the white majority to provide literacy to African Americans. Though there were many efforts from white agencies and philanthropists, particularly through the Freedmen's Bureau, to organize and open 
schools throughout the south, efforts were slow and some promises never materialized. Consequently, African Americans began to assert agency and pool resources to open schools for themselves because among the acquired understanding of the importance of literacy was also an acquired awareness that literacy was indeed their only hope for upward mobility.

\section{Limitation of Other Resources for Upward Mobility}

Though there were a very few exceptions to this rule, African Americans were largely disenfranchised as a result of the many political changes of the mid-to-late nineteenth century. Slavery and the Civil War had left them separated from family. Emancipation had left them without employment, possessions, or capital. The centuries of servitude had left them largely without education and without means by which to acquire these things so desperately needed for survival, not to mention social mobility. However, literacy seemed to be a common denominator in acquisition of all other necessary means of survival. It could provide the ability to write and locate family members, to secure meaningful employment (though this notion would be challenged more than most freedmen realized), and employment could yield possessions and capital. It seemed a plan to which the African-American masses subscribed because literacy was finally within their reach, and it was the only legitimate resource they had available.

Leonard Curry, in his text The Free Black in Urban America, 1800-1850: The Shadow of the Dream (1981), argues that because of the limitations of other resources, African Americans were probably more inclined to embrace and pursue education than their white counterparts: 
It is possible that blacks, because they largely lacked such other instruments of advancement as family influence, access to capital, relative freedom from class restraints, and community acceptance of their aggressiveness and ambition, placed greater faith in the liberating qualities of education than did the whites and, hence, sought its presumed benefits more earnestly. (148)

Curry's argument is a valuable insight into why $19^{\text {th }}$-century African Americans developed a sense of urgency to acquire literacy. Assuming that literacy learning is the only resource to which African Americans had sufficient access, it is not at all surprising the 1860 s proved to be a time characterized by a widespread growth of schools for African Americans, particularly in the South. Conceptually and theoretically, literacy became a useful tool, not only to the African Americans in pursuit of it, but also to a large part of the American public who feared the social implications of this newly free and largely illiterate population (see Chapter Two).

\section{The Utility of Literacy}

\section{Political and Social Reform}

As mentioned in Section Two, the mid-to-late nineteenth century was marked by major social and political change. The country found itself rebuilding after years of civil war, as well as addressing the question of what to do with the abundant, newly freed population of African Americans. Many citizens, particularly members of the Republican Party, argued that having this largely illiterate population threatened social stability; therefore, literacy became a tool of assimilation and hegemony for the country (Graff, McAfee). Nationwide efforts at funding and providing formal schooling at varying levels 
were prominent following emancipation. The majority culture was concerned about the impact that vast numbers of free, illiterate people would have on the quality of life in American society and began campaigns for opening schools to rectify the situation. Though this issue is more extensively discussed in Chapter Two, it is useful to assert it here for an understanding of the utility of literacy for both the white and black populations.

The acquisition of literacy would in essence have a dual purpose. It would serve the needs of upwardly mobile African Americans, as well as the need for hegemony among the multicultural masses. There are many slave narrative accounts in which African Americans discuss "why" they desired to learned to read. Many of the responses were pragmatic ones (Williams 41). A common response was to read the Bible; however, literacy was useful to African Americans in other ways: teaching their children, recording family and social events, conducting business by artisans and craftsmen, and locating family separated by slavery and war. Literacy was useful because it provided African Americans with the ability to more completely participate in society. Full participation in society would not only allow them to apply literacy to the practical task of their daily living, but also to assert agency beyond their immediate sphere to bring about social change.

\section{Role in Establishment of Community}

One of the more useful functions of literacy for African Americans is the use of writing for self-advocation. The newly freed African American had few allies, but their social and political issues were legion. The ability to read and write gave them the right to assert agency in many ways: "In newspaper editorials, letters to public officials, 
speeches at conventions, and statements to white citizens, black individuals and organizations demanded land, enfranchisement for black men, the right to testify in courts, fair compensation for their labor, and the right to compete economically. They also asserted a right to education" (Williams 69). The agency that the ability to read and write afforded African-American citizens was valuable, and many African Americans jumped at the opportunities. These opportunities shaped their ability to understand the importance of agency and to understand the strength in numbers. Therefore, literacy provided a foundation for the development of community among African Americans, not the ones in secret that had existed in slavery, but ones that embraced the desire to fully participate in a democracy.

One of the most prevalent manifestations of the sense of community was the commitment to which African Americans came to provide schools for their own children. Though benevolent schools funded by northern philanthropists were certainly widespread, many African Americans did not embrace these schools, especially when the faculty was exclusively white. African Americans wanted to ensure that their children, who were often involved in literacy learning at tremendous economic sacrifice, were receiving the best quality education possible, and many did not trust that benevolent/philanthropic schools could, or would, provide this kind of instruction. One way to ensure that African-American children had access to the kind of education those in the African-American community desired was to provide schools for themselves.

\section{Sponsorship}

In order for African Americans to acquire literacy, there had to be people and agencies willing to provide instruction. Those who provided literacy, either through the 
varying levels of instruction or funding, were known as sponsors, and sponsors were a very important aspect of literacy learning for African Americans. The resources available were limited; therefore, the importance of the role of sponsors cannot be underscored. Deborah Brandt has demonstrated the importance of literacy sponsors in determining who has access to literacy, as well as how individuals access different forms and levels of literacy. Brandt defines sponsors as "any agents, local or distant, concrete or abstract, who enable, support, teach, model, as well as recruit, regulate, suppress, or withhold literacy — and gain advantage by it in some way" (166). Brandt further argues that "sponsors are delivery systems for the economies of literacy, the means by which these forces present themselves-to and through—individual learners" (167). Literacy learning in Louisville, Kentucky in the nineteenth-century was sponsored through various agencies, primarily churches. This dissertation explores issues of sponsorship in the state of Kentucky and the city of Louisville, seeking to expose manipulative practices of the white majority and the African-American commitment to literacy learning for an entire community.

Sponsorship for African-American literacy through formal education fell into three categories: entrepreneurial, institutional, and philanthropic. In entrepreneurial schools, costs were defrayed through payment of tuition on a per student basis. Institutional schools were oftentimes sponsored and housed in churches or other organizations, and often the cost of the instruction might be covered by the institution, but students paid nominal tuition to cover costs other than facility and instruction. Philanthropic schools were often organized and funded by a group or individuals outside the African-American community; sometimes tuition was assessed, but general services 
were still rendered to those who could not pay tuition (Curry 148). Louisville was unusual in that prior to emancipation and the $13^{\text {th }}$ amendment, there were nine privately sponsored African-American schools functioning: three were entrepreneurial, mostly taught in teachers' homes; four were institutional, housed in churches; two were philanthropic, one sponsored by the American Missionary Association and another operated from charitable donations from the community (Doyle 8-9). This aspect of Louisville's antebellum history offers a context for considering the importance of and commitment to literacy learning in this community. Self-Sponsorship-The State of Kentucky. . The City of Louisville

Brandt's definition provides a conceptual frame for considering African Americans as primary sponsors of their own literacy. I argue in Chapter Three that the primary sponsors of African-American literacy in general are African Americans. Though that sponsorship came through a number of entities (the African-American church, mission and charitable schools, as well as secular community leaders), those at the very heart of transmitting literacy to African Americans were African American. African Americans were the primary sponsors of literacy in their own communities; however, there were many benevolent organizations, both privately and federally funded, that contributed to funding of schools throughout the country and in Louisville after Emancipation; therefore, I do acknowledge that African Americans were certainly not the sole sponsors of African-American literacy.

In the state of Kentucky, African Americans developed a system through which they could sponsor their own schools. In 1866, the African-American leadership, which consisted largely of ministers and educators throughout the state (many of whom were 
residents of Louisville), urged the state legislature to enact a law excising an additional tax of $\$ 2.00$ to be levied against "every male Negro and mulatto over the age of eighteen years" (Doyle 50). This tax would be collected in addition to, and in the same manner as, all other taxes so that the trustees of each school district "may cause a separate school to be taught in their district for the education of the Negro and mulatto children in said district" (Doyle 50). The act also called for funds to be used to care for the paupers of the race. Initially the funds were designated to finance schools for African-American children and the "revenue" of the account was supposed to be allocated to care for the paupers. However, this law would undergo two major transformations in less than two years that would ultimately impede schools from receiving any of the designated funds

(Doyle 52-54). A statewide, financial "cat and mouse" game would ensue (which Chapter Two discusses in detail), and public schools for African Americans did not open in Louisville until 1870 , four years after legislation was passed.

\section{Louisville, Kentucky: Context for a Case Study}

\section{Louisville, Kentucky—A Unique Place with a Unique Set of Circumstances}

In the nineteenth century, Louisville was a major city in a border state. Though Kentucky was a slave state, the unique circumstances for slaves in the city of Louisville created an unusual environment for the African-American community. In this dissertation, I offer Louisville as a case study. I explore the role of literacy in AfricanAmerican lives in the nineteenth century, public discourse surrounding the development of public schools in the nation, the state, and in Louisville, and Louisville's unique cultural circumstances during this time. I also explore the nature of the Louisville 
environment, and the social implications of the unique circumstances that existed pre and post emancipation.

Studies of African-American Literacy and Histories of African-American Schools

Many scholars have contributed valuable studies of the development of schools for African Americans; a few have focused on the state of Kentucky and the city of Louisville. George D. Wilson contributed one of the first comprehensive accounts of the development of schools in Louisville in his text $A$ Century of Negro Education in Louisville, Kentucky. The data from this text, in its original version (1941), were collected as a result of a federally funded project, The Works Project Administration. Wilson, a professor at Kentucky State University at the time, was chosen to lead the work of collecting and documenting "a history of Negro education in Louisville" (iv). Though this work was never officially published, primarily due to the expiration of federal funding, the information was verified by administrators at both Louisville Municipal College and the University of Louisville, and the text was bound and placed in the Louisville Free Public Library, the University of Louisville library, Kentucky State University library, and the Filson Club, now the Filson Historical Society (iv) $(1941 / 1986)$.

Standing on the shoulders of Wilson, Ruby Wilkins Doyle published a provocative collection of excerpts of primary documents in Recalling the Record: A Documentary History of the African-American Experience within the Louisville Public School System of Kentucky (2005) that has been extremely useful to my research. This text provides a chronological representation of excerpts from newspaper articles as well as legislative and municipal documents. Little is offered in the way of analysis, save very 
general commentary between primary text excerpts, but, like Wilson, her purpose is to inform, not analyze. The sole purpose of her account of the early history is to create a backdrop for the real focus of her work, which is the history of Louisville Central High School, the first African-American high school in Louisville. Nevertheless, Wilkins' text has been very valuable and provided a foundation for this research project.

Wilson's and Wilkins' texts are the only two devoted to telling the history of African-American schools in Louisville; however, two texts are devoted to a more general history of African Americans in Louisville (Cummings and Price, Wright). The Cummings and Price text, Race Relations in Louisville: Southern Racial Traditions and Northern Class Dynamics (1990), finds its focus in race relations and analyzes the cultural clash between the race cultures in southern and northern class dynamics. This text situates the race relations in Louisville in a national context and helps a reader to understand the unique racial climate that existed in this city. Like Wilkins' text, George C. Wright's Life Behind a Veil: Blacks in Louisville, Kentucky, 1865-1930 (1985) has provided very specific historic as well as cultural details about the African-American community in Louisville. Wright's purpose is to deconstruct what he identifies as the concept that Louisville was a racial Mecca, and he seeks to challenge historical treatments of race relations, while at the same time acknowledging that race relations in Louisville were indeed unique. Wright calls the relationship between whites and blacks one of paternalism and claims that though whites were supportive of blacks, their support "demanded that blacks be passive and remain in the place assigned them in Louisville Society" (2). 
Other valuable texts include Henry Clay Weeden's book, Weeden's History of the Colored People of Louisville (1986), and J. Blaine Hudson's dissertation, "The History of Louisville Municipal College: Events Leading to the Desegregation of the University of Louisville" (1981). Hudson does an extensive rhetorical analysis of the Board of Trustees minutes for the opening of the University of Louisville and the funding of Louisville Municipal College, and the history of the opening of public schools serves as a historical backdrop to the focus of his discussion. In addition, Louisville's history has also been included in texts that give an account of the general history of blacks in Kentucky (Clark, Dunnigan, Howard, Lucas, McDougle, Venable). Though Louisville's history is a unique one and worthy of extensive analysis, these are the few texts devoted to its account. However, there is a greater body of scholarship on the development of schools for African Americans in the South and in America, most of which has limited information on the state of Kentucky (Anderson and Moss, Bullock, Vaughn, West, Woodson). Though these texts do not offer the kind of detail necessary to evaluate the Louisville phenomenon, they are useful in situating this dynamic in a larger regional and national context.

Texts devoted to a general account of the history of education in America have also been useful. A watershed text is Lawrence Cremin's American Education, the National Experience, 1783-1876, a comprehensive text that explores the relationship between educative institutions such as the household, the church, the school, and the newspaper. Likewise, E. Jennifer Monaghan's Learning to Read and Write in Colonial America contains a chapter entitled "Literacy of the Enslaved," which sheds some foundational light on the historical role of literacy in the African American experience. 
Herbert Kliebard's text The Struggle for the American Curriculum does not address the education of blacks in any level of thoroughness; however, his discussion is primarily about the evolution of an American educational system for mainstream America, which analyzes issues of gender and class. Finally, Nasaw's Schooled to Order and McAfee's Religion, Race, and Reconstruction discuss extensively public schools and race relations and the irony of having a "separate" "public" institution (McAfee 81).

Another useful body of research is scholarship in African-American literacy. The quintessential texts of this area of research are Jackie Jones Royster's Traces of a Stream, and Soldiers of Light and Love and Shirley Wilson Logan's With Pen and Voice and We Are Coming. However, given the financial nature under which African-American schools were funded, Deborah Brandt's article "Sponsors of Literacy" in CCC 49.2 is most useful in understanding how African Americans in the Louisville area were able to realize their pursuit of literacy. Brandt's definition of sponsors presents an interesting framework, given the tax African Americans in Louisville requested to pay for their own schools, and that those funds were withheld for a period of time and used for other purposes.

The final body of research relevant to the rhetorical analysis of the documents is critical race theory. Critical Race Theory (CRT) provides a lens through which to analyze seemingly ordinary societal phenomena from the perspective of the so-called other. This theory is structured around four hallmark themes: material determinism, revisionist history, critique of liberalism, and structural determinism. The theme most relevant to my analysis is that of revisionist history. CRTs believe it is necessary to reexamine events in history and replace "comforting majoritarian interpretations" with 
more accurate "minorities' experiences" (Delgado and Stefancic 20). Often revisionists' interpretations have a materialist and structuralist component to their arguments, as is the case with this project.

Using these texts for context, this project examines public discourse of both the African-American and white majority communities about education, in particular public schools, for African Americans. Many of these documents contain arguments in support of governing bodies making provisions for African-American education, but oftentimes justification or support for these arguments rests on decisions beneficial only to the majority community, or in the case of African-American discourse, highlight the generosity of the majority community. McAfee, in Race, Religion, and Reconstruction, argues that public education was designed as a tool for assimilation of various ethnic groups, African Americans included. Likewise, in 1872, Superintendent of Public Instruction H.A.M. Henderson argues in his report to Kentucky Governor P.H. Leslie that it makes sense to facilitate the opening of schools for African Americans because of the passing of the $15^{\text {th }}$ Amendment: "A naturalized Guinea negro at the polls wields as much power as the most cultivated Caucasian" (45). McAfee's argument and Henderson's perspective for providing public education for African Americans provide support for CRTs' belief that even when watershed events occur in race relations further research will prove that there is some self-serving undercurrent for the majority. This project will explore this ideology as educational opportunities emerge for African Americans in Louisville during the late nineteenth century. 


\section{Archival Discovery and Valuable Sources}

My Scholarly Position

In the spirit of Royster's work in Traces of a Stream, I would like to discuss the origin of this project and my personal as well as scholarly investment in the history of African-American literacy in general and the city of Louisville, Kentucky in particular. This project began as the fulfillment to an assignment for a course in the History of Rhetoric. Dr. J. Carol Mattingly instructed our class to go into an archive and research a topic of our choice from the eighteenth or nineteenth centuries. Because I have always loved school and spent my entire adult life working in education, a number of years at the secondary level, and also because I am a native Louisvillian and grew up in the predominantly African-American West End, I decided to research the first AfricanAmerican school in Louisville, Kentucky. Little did I know that this experience would evolve into a project that I would live with for the next two years.

Part of what I believe makes literacy such a powerful force is that those who command the language have the power. Though many contemporary scholars (Smitherman, Richardson, Horner and Lu) argue against notions of a power language, history has proven that he/she who has the language has the power. That has been demonstrated through the experiences of African Americans in slavery, Native Americans in the confiscation of their lands, and European immigrants in their subjection to demonstrations of literacy for citizenship. I do not know at what time in my life I realized the importance and power of literacy, but I know that in my tender years I always found personal reward in being lauded as smart and eloquent, and it was not until 
my mature years that I realized part of what I was being lauded for was the fact that I was exceptional because I was smart and eloquent and black.

I have written personal writing samples about myself and my brother and our very different literacy experiences. My reflection of this charmed literacy experience for myself, as the smart and eloquent African-American girl, and for my brother, as the academically challenged African-American boy, has made the discovery of the history of African-American literacy in Louisville even more profound. I grew up in this community and was educated in the predominantly white school system outside the urban areas; yet, this is a history about which I knew nothing. This discovery has helped me to reflect on education in many ways. It has impacted the way I position myself as an African-American teacher and scholar, the way I view African-American students and the literacy baggage they bring with them to institutions with expectations of smartness and eloquence, and the way I view majority culture's definitions of what counts as literacy in contemporary academic environments. This project has been a journey, one that has fostered as much self discovery as scholarly discovery. The discoveries along the way have been a revelation as well as a reflection on cultural decisions about what and whose histories get preserved.

In Search of Lost Histories

Historical narratives of marginalized populations are most often reconstructed through fragmented documentation, and Louisville's African-American literacy narrative is no different. Archival work included trips to the Louisville Public Library Main Branch Archive, the Filson Historical Library, the Kentucky Department of Libraries and Archives, the University of Louisville Archive, and the National Archives and Records 
Administration in Washington, D.C. Visits to each archive yielded what initially seemed to be very small pieces to a very large puzzle; however, the pieces that have been recovered are very telling.

A trip to the main branch to the Louisville Public Library archive was an interesting discovery. Amid the many documents crammed into boxes without effort toward care or preservation were newspaper articles about the opening of AfricanAmerican schools in Louisville in the very early twentieth century. Initially, I was impressed by Louisville's commitment to educating African Americans, and I was also completely struck by the hundreds of thousands of dollars whites were willing to spend to keep their children from attending schools with blacks. Upon further investigation beyond the public library archive, I discovered the African-American school tax from the nineteenth century; my impression was changed, and I became very interested in AfricanAmerican Louisvillians and self-sponsorship.

A visit to the Kentucky State Archive yielded several legislative documents, including the three different versions of the education tax laws and annual reports from the state superintendent of schools to the governor of Kentucky. My trip to the University of Louisville Archive yielded many rare texts on Louisville's local history as well as access to the Jefferson County Public Schools archival information (which was surprisingly disappointing and not very useful). A trip to the National Archives in Washington D.C. yielded the most promising discovery; I found in the Freedmen's Bureau Papers, handwritten letters from citizens in Kentucky advocating for assistance with schools for African Americans. Though the various pieces I have discovered do not in any way provide a comprehensive look at literacy learning and schooling in Louisville 
in the nineteenth century, the fragments do offer enough of a snapshot that we as an audience, through inductive reasoning, can understand what the issues were and how both white and black populations addressed them in public discourse. In his book Liberation Historiography: African American Writers and the Challenge of History, 1794-1861, John Ernest argues "for African American historians, the fragments themselves were the history, and the only narrative to be constructed from the fragments that could represent the history indicated $b y$ the fragments was itself a fragmented narrative" (100). However, I offer a different view: offering a narrative from fragments might be problematic, but offering a case study, an opportunity to evaluate what clearly exists and draw conclusions from it, leads to a more comprehensive understanding of a particular cultural environment at a given time.

\section{Limitations of Historical /Archival Research}

Archival work, though at times exciting, oftentimes is difficult and problematic. Probably the biggest problem is preservation. Throughout this process, the minimal efforts at preservation have been shocking. At the Kentucky State Archive, when requesting minutes from state legislative meetings (as I was more interested in the discourse prior to the passing of legislation than the legislation itself), I was shocked when I was told they had been sold for scrap paper during The Depression. I was also disappointed to learn that very few speeches of the African-American leadership of Louisville have been preserved. Though there are many secondary reports of the lobbying and self-advocating for literacy and schools occurring within the African-American community and beyond, the words of many African Americans have been forever lost. I was hopeful that I might find transcripts of two major statewide conventions held by 
African-American leadership throughout the state of Kentucky, but I was unable to locate minutes or speeches, just very little commentary in local newspapers. Finally, I was excited to learn when the first two public schools for African Americans were opened, African-American women were appointed as principals, but I was disappointed to learn that they seemed to just fade into the annals of history. However, despite the barriers, what sources I did locate have led to this study.

Primary Sources

As mentioned earlier, probably my single greatest discovery was Ruby Wilkins Doyle's text, Recalling the Record. Doyle's work really did eliminate many hours of searching into the abyss. Though her work does not offer any analysis, she produced a comprehensive collection of primary documents which consist mostly of newspaper articles as well as legislative and municipal documents, chronicling the AfricanAmerican experience in the history of public schools. Often her references are partial reproductions of texts; however, the fact that she had completed so much of the preliminary work made this project manageable in a much tighter timeframe.

The discovery at the national archives moved this work forward in a meaningful way. I had originally started with the belief that what was happening with literacy in nineteenth-century Louisville was unique and different from the kinds of efforts that were occurring in other cities. Those beliefs were confirmed when I was able to substantiate that discussions of schools in Louisville, as well as other parts of Kentucky, had been included on the national agenda of the Freedmen's Bureau because citizens were writing letters advocating for justice. I think Dr. J. Blaine Hudson said it best, "What was happening in Louisville was not happening because it was such a unique place, but 
because Louisville had a very unique set of circumstances" (interview). Chapter three is devoted to highlighting those particular and unique circumstances.

Because I have limited my study to an analysis of public discourse, I struggled to locate representations of African-American voice. Local newspapers generally highlighted the majority culture's perspective. Unfortunately, Louisville did not have an African-American publication in the nineteenth century; however, the database African American Newspapers: The Nineteenth Century did provide some useful issues from newspapers outside the Louisville area. Even though Louisville did not have an African merican publication, citizens of Louisville, as well as other parts of Kentucky, did contribute articles about local phenomena to African-American newspapers in other parts of the country.

The role of the African-American newspaper in the nineteenth century was vital to the African-American community. It was a source of information and encouragement, but it was also a place where their voices could be heard, especially against the many injustices that they endured in their daily lives. After the war and emancipation, the African-American newspaper evolved from a source of anti-slavery, anti-injustice propaganda to a source of literacy, community, and agency for African Americans. One newspaper, The Christian Recorder, served to some degree as a national newspaper for African Americans. Based in Philadelphia and sponsored by the African Methodist Episcopal Church, The Christian Recorder had a widespread readership. Many issues of this newspaper provide reports of the "goings-on" in various African-American communities throughout the country. Many communities took advantage of the opportunities to sometimes vent, but more often than not, to celebrate their many 
accomplishments. I was surprised and excited to discover the reports on schools from Louisville and other parts of Kentucky, and I offer a discussion of these in Chapter Two and Three.

Secondary Sources

Discussion of my use of secondary sources in this study causes me to return to my metaphor of fragmented narratives. Three valuable bodies of research help to contextualize the Louisville experience. The most useful are the studies of literacy provided by Graff, Royster, Williams, and Cornelius. Beyond literacy scholarship, I have to be concerned about various histories of public education, and Ward M. McAfee has certainly been my most reliable source for historically framing what happens in Louisville against what is happening throughout the country. Finally, many sources on Louisville and Kentucky history have been valuable in helping me to situate my argument in the concrete. Both Wright and Lucas enlightened Louisville from a historian's perspective, which aided in my rhetorical analysis of the various documents I have discovered. However, without a doubt, the most valuable resource and guidance for the historical particulars of this project came from a living history in a man who carries a love and passion for the particular nuances in Louisville's history that I so desperately needed to complete this project, especially Chapter Three, Dr. J. Blaine Hudson. I have attempted to triangulate my findings from these three bodies of information in order to offer a detailed snapshot of the acquisition of literacy and the development of schools in Louisville 1860-1873. 
Research Questions

Many research questions have guided this study. My global question as I encountered the various primary sources in my archival search has been: What rhetorical strategies are employed when making arguments for and against the opening of public schools for African Americans in the city of Louisville, Kentucky in the years immediately following emancipation? Additional and more specific questions that have guided my research are as follows:

- How did African Americans approach the notion of literacy and education? How did they view literacy? What were its purposes and importance for them?

- How did whites' views of literacy for African Americans differ from those of African Americans? What were its purposes and importance for them?

- Scholars in Rhetoric and Composition argue that historiography is important to our field of study, particularly when studying marginalized populations. What are the social implications of this historical phenomenon and how can this localized dynamic be situated in the larger nationwide conversation?

- What does the series of events surrounding the opening of schools for African Americans indicate about education, particularly that of marginalized peoples, and how it has been posited as a privilege rather than a right to some peoples?

- How can the study of historical phenomena inform how we teach and study rhetoric and composition students today and in the future?

\section{Description of Chapters}

This dissertation is divided into four chapters. Chapter One offers a brief introduction on the importance of cultural historiography, as well as an overview of the 
role and function of literacy in lives of African Americans pre and post-emancipation. This chapter also offers an overview of the most relevant literature regarding historical studies of literacy, cultural studies of literacy, sponsorship of literacy, histories of public schools, and histories of Louisville, Kentucky. Finally, it describes methodological practices and a description of the project. Chapter Two examines the history of public education in a national and state context, using Critical Race Theory as a theoretical framework and offering rhetorical analyses of various national and state legislative documents and other forms of public discourse. Chapter Three offers Louisville, Kentucky as a historic case study for examining how an established and empowered community of free blacks exercises agency in their pursuit of literacy and public education. This chapter paints a geographic, historic, and cultural picture of nineteenthcentury African-American Louisville and offers an examination of the cultural landscape and local rhetoric, primarily in newspapers, surrounding the opening of public schools. Finally, Chapter Four offers conclusions and social implications for what this cultural literacy narrative means to scholarship in general and Rhetoric and Composition in particular. 


\section{CHAPTER TWO}

\section{From Literacy Learning to Formal Education: \\ The History of African-American Schools}

\section{INTRODUCTION}

The journey to formal education for African-Americans in the state of Kentucky was similar to other states with comparable conditions. Kentucky was one of the few states that never passes laws forbidding the education of African-American free men and women or slaves, even prior to emancipation. Kentucky was a border state. The Civil War dynamics in the Border States in some ways were much more intense than that of the southern slave states. Because these states bordered free states, there were really strong factions on both sides of civil war issues, literally brother against brother and community against community. Kentucky had traditionally prided itself on neutrality during the Civil War. However, the reality of that claim is skewed. Kentucky was a slave state with union sympathies, though there were Kentuckians who fought on both sides of the Civil War. This phenomenon likely led to this rhetoric of neutrality.

\section{The Conditions of Reconstruction}

Post-War Economy

It is fair to say that the battle for public education was just as much a Caucasian battle as it was an African-American battle, especially in the South. The union had triumphed over the confederacy, slaves had been freed, and the workforce was flooded 
with unskilled labor in an ever growing industrial economy. Former slaves had been turned out into a workforce that had a surplus of field hands. Former slaves with domestic and craftsman skills were far more marketable but fewer in numbers than those who had only worked in the fields. Fewer craftsmen were employing apprentices because much of the labor was now being performed by machinery. Consequently, crime and vagrancy among young people and African-Americans were becoming increasing problems (McAfee 1-2).

\section{The Republican Agenda}

The push for national public education emerged out of these economic conditions. Though public education had been on the northern agenda for some time, the push for national attention for public schools became the Republican Party's post-Civil War agenda. Public education for the Caucasian masses was still very much in the developmental stages in the United States, in particular the South, and the push for separate schools for African-American education joined this issue on the national agenda.

The Republic Party may have been the catalyst, but Northern benevolent associations were clearly on board. The American Missionary Association (AMA) was the first northern group to sponsor African-American education. Though this organization was not associated with any one denomination in particular, many denominations designated the AMA "as their agent for educational and religious work among freedmen" (Vaughn 4). Many members of the AMA were Congregationalists, so the agency was sometimes referred to as the Congregational missionary organization. However, other denominations that selected the AMA included Freewill Baptists, Wesleyan Methodists, and the Dutch Reformed Church (Vaughn 4). Another agency involved in aid and 
education of the freedmen was the American Freedmen's Union Commission (AFUC). Though the AFUC was a short-lived agency, it represented many nonsectarian groups in the campaign to aid and educate African Americans (Vaughn 5). Ultimately, the federal government became involved in the educational of African-Americans primarily out of necessity. In November 1862, General Ulysses Grant became concerned about the number of contrabands entering occupied union territory. Grant decided they should be taught then put to work. Grant appointed Colonel John Eaton, a former school superintendent from Ohio, to the position of superintendent of Negro Affairs. Eaton divided the occupied areas into districts, appointed superintendents, and hired teachers (Vaughn 5). These initiatives and similar ones ultimately led to the federal government's decision on 3 March 1865 to establish a central organization to manage education and aide to African Americans, the Bureau of Refugees, Freedmen and Abandoned Lands, more commonly referred to as the Freedmen's Bureau (Vaughn 9).

\section{The Push for Public Schools: A Tool for Assimilation}

The Civil War had been fought and won on free labor ideology. The concept of free labor asserted that slavery was bad for the economy and that independent white males needed to be able to compete in a free and fair market in order to maintain economic independence. Now that the Republican Party had eliminated human slavery with the free market principles, they were committed to stamping out ignorance as well. Northern agencies felt that northern involvement in the establishment of public education for African Americans was essential. Leaving the education of the newly freed African Americans in the hands of white southerners seemed completely irresponsible. Education and literacy became as much a moral issue as a social one. Public education would be 
designed to teach moral values and make good citizens of illiterate blacks and Southern whites. In his text Religion, Race, and Reconstruction: The Public School in the Politics of the 1870s (1998), Ward M. McAfee argues that "the primary purpose of the public school was to create a common behavioral code for the entire society. Just as new machines turned out standardized products, the public school was intended to standardize society" (9-10). The public school became the Republican Party's first of many steps toward homogeneity after the abolition.

Obviously, northern agencies and benefactors felt that establishing schools for African Americans was a much safer project in their own hands. There was a particular distrust toward white Southerners, and there were serious concerns about African Americans' ability to conduct their own schools, even though African Americans had been conducting private schools for many years during slavery and after emancipation. Literacy learning was conducted both in formal and informal ways. One of the most effective and consistent sources of literacy learning was Sunday school. As Curry points out "the black Sunday school differed from its white counterpart not only in its greater emphasis on developing literacy but also in serving a large number of adult pupils"(155). Sunday schools had a captive audience in a safe space, where literacy was the focus, which would ultimately allow African Americans to become able students of the scripture. With the growing increase of African Americans enrolled in schools came the steady increase in the demand for teachers, in particular African-American teachers. 


\section{National Conversations about Public Schools for African Americans}

Freedmen Bureau Agenda and Papers

The Freemen's Bureau Papers housed at the National Archives in Washington D.C. tell an interesting story about Kentucky schools sponsored by the Freedmen's Bureau. In the Consolidated School Report to Bureau of Refugees, Freedmen, and Abandoned Land for the Six Months Ending January 1, 1869, the number of Bureau sponsored schools was recorded according states. The report collapsed District of Columbia, Delaware, Maryland, and West Virginia into one column, and columns for other states were listed in the following order: Virginia, North Carolina, South Carolina, Georgia, Florida, Alabama, Mississippi, Louisiana, Texas, Arkansas, Tennessee, and Kentucky, with Missouri and Kansas listed together in the final column. In comparison to other states listed on the report, Kentucky offered more schools than most other states. Kentucky reported 212 day schools and 37 night schools. The only state that exceeded Kentucky was Virginia with 238 day schools and 38 night schools. Also, North Carolina, though it fell behind Kentucky in day schools at 192, offered 39 night schools. The other startling statistic for Kentucky on this report was with the number of teachers. Of the 268 teachers in the state of Kentucky, $222(82.8 \%)$ of them were African American and only $46(17.2 \%)$ white (1). These numbers represented the commitment to literacy in Kentucky's commonwealth as well as the commitment of the African-American community to being an active sponsor of their own literacy.

Another document of particular interest in the Freedmen's Bureau Papers was the Seventh Semi-Annual Report on Schools dated January 1868 for the state of Kentucky submitted by Colonel Ben Runkle Assistant Commissioner and T. K. Noble 
Superintendent of Education for the Bureau. Runkle and Noble offered a collaborative report of all the educational activity in the state of Kentucky and what was compelling about this report is that it contained recurring reports of violence against colored schools, students, and teachers. For every positive report of school openings there were others of church/school burnings, of mobs forcing teachers out of the city: "The building known as the Noble school was burned to the ground on the night of October $1^{\text {st }}$. Two churches in Bullitt County used for school purposes, were also burned on the same night" (174). In the very next section, the report stated, "at Mayfield, on the morning of the $30^{\text {th }}$ of October, the KuKlux, about fifty in number, after robbing and severely whipping a number of freedmen, proceeded to the boarding place of the teacher, a young colored lady educated at Oberlin, and drove her from the town" (174). The reports of burnings and violence toward teachers were too numerous to include them all, and too sad to linger. Weaved into the various tragic narratives, were repeated cries for the need of troops to bring order to the chaos that existed throughout the state.

One narrative included in the report that is worthy of examination was the contributions that the African-American communities were making to the establishment of their own schools. After listing a table containing the size and locations of 22 schools that had been erected since June 30, 1868 (the date of the last report), the report stated, "Eight of the above buildings were erected by the freedmen without aid from the Bureau. To the remainder the Bureau has rendered assistance amounting in the aggregate to $\$ 4282.55 / 100$. It appears that during the last six months the freedmen of Kentucky have contributed from their poverty $\$ 14,567.45$ for schoolhouses in which to educate their children" (182-183). Of all the historical information recorded in this project, this fact 
seems to be the most profound. The African-American communities throughout the state were not choosing to rely exclusively of the assistance of the federal government, but rather were actively sponsoring their own schools at an astonishing rate.

\section{State Conversations about Public Schools for African Americans}

Pre- and Post-War Literacy Rates

As would be expected, literacy rates in the state of Kentucky were low among African Americans immediately before the war, and with all of the initiatives for educating the newly freed rates steadily increased after the war. In 1850 , the state of Kentucky had 220,992 African Americans: 210, 981 slaves and 10,011 free people of color. The number of illiterate free people of color was $3,019,30 \%$ of the total free population. In 1860, on the eve of the Civil War, the total African-American population in Kentucky was 236,167 . The slave population for the state totaled 225,483 , and the number of free people of color was 10,684. The number of non-literate free African Americans in the 1860 was 2,463 , a reduction to $23 \%$ of the total free African-American population. Illiteracy, in both the 1850 and the 1860 censuses, was defined by people aged 20 and above with the inability to "read and write" (Compendium of the Ninth Census).

Table $1 \quad$ Kentucky African-American Literacy Rates

\begin{tabular}{|c|c|c|c|c|c|}
\hline Census & $\begin{array}{c}\text { Free } \\
\text { People of } \\
\text { Color }\end{array}$ & Slaves & $\begin{array}{c}\text { Total AA } \\
\text { Population }\end{array}$ & $\begin{array}{c}\text { cannot } \\
\text { read and } \\
\text { write }\end{array}$ & $\begin{array}{c}\% \\
\text { Illiteracy }\end{array}$ \\
\hline 1850 & 10,011 & 210,981 & 220,992 & 3,019 & 13.6 \\
\hline 1860 & 10,684 & 225,483 & 236,167 & 2,463 & 10.4 \\
\hline
\end{tabular}


In the 1870 census, definitions of literacy changed significantly, complicating a comparative analysis. By this time, the Civil War has been over for five years, and all African Americans are free people of color. Though statistics are still being catalogued by race in most respects, they are complicated in measurements of literacy. The total population (both black and white) for Kentucky in 1870 is 1, 321,011. African Americans comprise 222, 210 of that total. In the 1870 census, literacy has been broken down into separate statistics for the ability to read and the ability to write, and though this breakdown alone is not that complicated, the statistics for the ability to read are not catalogued by race. The census indicates that of the $1,321,011$ people in the state of Kentucky, 249, 567, over the age of ten, cannot read; therefore, $16.8 \%$ of the total population cannot read. However, the statistic for the ability to write is catalogued by race. Of the 222, 210 African Americans in Kentucky, 131, 050, over the age of ten, cannot write-translating to almost $59 \%$ of the African-American population (Compendium of the Ninth Census).

Table 2 Kentucky Literacy Rate for Reading and Writing

\begin{tabular}{|c|c|c|c|c|c|c|}
\hline Census & $\begin{array}{c}\text { Total } \\
\text { Population }\end{array}$ & $\begin{array}{l}\text { Number of } \\
\text { African } \\
\text { American }\end{array}$ & $\begin{array}{l}\text { Total } \\
\text { "cannot } \\
\text { read" }\end{array}$ & $\begin{array}{l}\text { \% of Total } \\
\text { "cannot } \\
\text { read" }\end{array}$ & $\begin{array}{l}\text { African Americans } \\
\text { "cannot write" }\end{array}$ & $\begin{array}{l}\% \mathrm{AA} \\
\text { "cannot } \\
\text { write" }\end{array}$ \\
\hline 1870 & $1,321,011$ & 222,210 & 249,567 & 16.8 & 131,050 & 58.9 \\
\hline
\end{tabular}

There are two issues that warrant discussion when analyzing these statistics. One issue is that officials in the years between 1860 and 1870 realized that there is a significant difference between the number of people who can read and the number of people who can write. What they likely found is that by and large, most of the population 
had learned to read, so collapsing the entire population into one statistic for the "cannot read" category yields a mere $16.8 \%$ of the total population. Even prior to emancipation, many slaveholders in Kentucky allowed slaves to learn to read to help them function more effectively at their stations; however, having the ability to write afforded African Americans far more liberties than were acceptable during slavery. Slaves with the ability to write could forge passes and permissions for travel and escape. So the ability to write was a much greater treasure for African Americans and a much more significant risk for slaveholders; therefore, the literacy practice of writing was not as widespread as that of reading. The 1870 statistics show a positive correlation between the age of African Americans and the percentage of African Americans unable to write. Among older African Americans, the numbers of those unable to write were drastically increased (Compendium of the Ninth Census). One inference that can be drawn from this statistic is that in the years immediately following emancipation, the focus on learning to read was a more immediate task for African Americans of all ages; however, the focus on the ability to write may have been a literacy practice initially targeted toward younger generations. Whatever circumstances might have contributed to the differences between those who could read and those who could write, Kentucky's literacy rates created fertile ground for the planting of schools throughout the state.

Kentucky State Laws Passed

African Americans in the state of Kentucky were eager to initiate public schools for their children immediately after Emancipation. Leaders from African-American communities throughout the state began to rally and lobby the state legislature for possible funding options for their schools. As early as 1866, African-American leaders 
had successfully petitioned the state legislature to open "common" schools for AfricanAmerican children. On 16 February, "An Act for the Benefit of the Negroes and Mulattos in this Commonwealth: 1866 "was passed to provide a funding source for this initiative (see Appendix for laws). From February 1866 to March 1867, this law would undergo two major transformations that would completely disenfranchise the AfricanAmerican citizenry (Doyle 49-55).

In order to appreciate the expediency of this act, it is necessary to situate this event within a national timeline. First, the Emancipation Proclamation consisted of two executive orders - the first, 22 September 1862, threatened to free all slaves in the Confederate States that seceded from the Union that did not return by 1 January 1863 . The second order, signed 1 January 1863 , named the particular states that were affected: Arkansas, Texas, parts of Louisiana, Mississippi, Alabama, Florida, Georgia, South Carolina, North Carolina, and parts of Virginia. Slaves were legally free in the aforementioned states, but because Kentucky had not seceded, it was not included in this second order. Many formerly confederate states followed the proclamation by passing laws against slavery; again, Kentucky was not one of them. Only the slaves in the states that had seceded from the union were actually freed. It was not until the passing of the $13^{\text {th }}$ Amendment, 1 February 1865 , that slavery and involuntary servitude were outlawed in the United States, except for as a punishment for crime for which one has been tried and convicted.

So understanding that in the state of Kentucky slavery was not officially abolished until the passing of the $13^{\text {th }}$ Amendment, one has to acknowledge that the state legislature passing an Act allowing for the collection of taxes from African Americans for the 
purpose of funding schools was quite an accomplishment. But in actuality it was a funding for the people by the people, which is again demonstrative of the strong cultural concerns African-Americans in the state of Kentucky had about education and literacy.

As unique and ingenious as this plan was theoretically, African Americans in school districts statewide found themselves victimized by the rhetoric of this tax law. As I mentioned before the law was passed initially on 16 February 1866 . In its original design, the law read as follows:

Be it enacted by the General Assembly of the Commonwealth of Kentucky:

1. In addition to the tax already levied by the laws of this commonwealth, a tax of two dollars shall be levied on every male Negro and mulatto over the age of eighteen years, to be assessed and collected as other taxes, and when paid into the Treasury, shall go into the fund aforesaid.

The first section of the law required that the tax, for the benefit of African Americans, be collected "in addition to" taxes already levied against this population's already meager earnings. African Americans had not asked that they substitute a previous tax for the allocation of this tax, but rather that they pay this tax over and above their current obligations. This section also specified that this tax should be deposited in a particular fund for "for the benefit" of those who paid it.

Section two stated that a roll would be established in each county to include all citizens who were responsible for this additional $\$ 2.00$ tax. Section three was 
complicated because it contained a clause with vague language that created a loophole for those who wanted to avoid enforcement:

3. The trustees of each school district in this Commonwealth may cause a separate school to be taught in their district for the education of the Negro and mulatto children in said district, to be conducted and reported as other schools are, upon which they shall receive their proportion of the fund set apart in this act for that purpose (my emphasis).

The use of the word "may" instead of the more direct "shall" allowed many counties to claim that they understood the law to mean that they were not required to use the funds collected for schools, but rather it gave them the option.

Section four required each county to certify the number of Negro and mulatto paupers in their county by the Auditor of Public Accounts, and based on this certificate, they would be eligible to receive their portion of this fund for said purpose. Section five designated that Chapter 88 of the Statues would regulate this fund, but that "no part of said fund shall ever be drawn or appropriated otherwise than pursuant to this act in aid of common schools for Negroes and mulattos." Section six stated that the Auditor shall apportion the "revenue" of this fund to be used for support of the Negro and mulatto paupers. The Act closed by stating that it would not interfere with the current system of tax collection and that the Act "shall take effect from passage." So sections four through seven clearly indicated that the fund had been established to fund schools, and in the event that the fund had a surplus (revenue), counties could apply for funds previously exhausted on their poor. 
The language in this first version of the law allowed for the indiscretion of many county and state officials. Funds were being collected and not distributed in counties throughout the state of Kentucky. By 9 March 1867, the Act had completely unraveled and significant revisions were made to the original law. The first section of the revised law reflected a drastic change in the law that was implemented to cover the improprieties of those managing the fund: "That the capitation and other taxes collected from Negroes and mulattos shall be set apart and constitute a separate fund for the support of their paupers and the education of their children, as hereinafter provided" (my emphasis). The Act now designated that the funds were to be collected for the purpose of caring for African-American paupers first and providing the education for their children was an added benefit. This revision allowed those collecting funds to award all funds to the socalled "care of paupers" in each county. The law no longer stipulated that the primary use of the fund was for establishing of schools and no longer allowed for the "revenue" to be used for paupers. It actually accomplished the very opposite. Section four clearly stated that the Act would now be "applied exclusively to the support of the Negro and mulatto paupers, and the education of Negro and mulatto children in the county in which it was collected." The legislature reversed the priorities for the funds and left African-American citizens in the state of Kentucky without a viable funding source for public schools.

Section six maintained the language of the first Act, stating that "the county may cause a school to be taught in their district for the education of Negro and mulatto children in said district" (my emphasis). Once again lawmakers included a clause that allowed officials to manipulate and abuse the funds and view schools as an option for each county. This section also designated that counties report the number of students in 
their districts to the superintendent of schools and an allocation of $\$ 2.50$ for each scholar who attended school at least three months would be sanctioned by the superintendent to be draw out of the "separate" county fund. The law further complicated the distribution of funds for schools by specifying a per pupil expenditure that would not be allocated until the student achieved a record three months attendance. Though there seemed to be some efforts at controlling the misuse of funds by getting a number of municipal officials involved in the distribution process, the vague language allowed to remain in the Act negated any chance of propriety.

The number of legal stipulations in the Act increased from seven sections in the first version, to eleven in the second. The additional stipulations included in version two indicated that the African-American populace in the state of Kentucky rebelled against the malignancy in the municipal and legislative offices. Section eight stated that citizens who owed money to a Negro or mulatto, usually as payment for work performed, should inform the sheriff of the obligation and withhold the $\$ 2.00$ school tax, or any tax for that matter, and make payment to the county on behalf of those African-American males. This addition to the Act indicated that apparently some African-American citizens avoided paying the tax, likely because of the misuse and abuse of the fund. The Act closed negating the previous Act and designating collection stipulations.

The final version of the Act, passed 9 March 1867, completely withdrew the funding of schools from the purpose of the law and designated the $\$ 2.00$ tax to be deposited in a fund for Negro and mulatto paupers only. The new law, titled "An Act To Amend 'An Act for the Benefit of the Negroes and Mulattos of This Commonwealth,', stated the following: 
Whereas: A difference of opinion exists in regard to the application of a fund authorized to be raised by an act, entitled "An act for the Benefit of the Negroes and Mulattos of this Commonwealth," approved March $9^{\text {th }}$, 1867:

Be it enacted by the General Assembly of the Commonwealth of Kentucky:

1. That no part of the fund authorized to be raised by the aforesaid act shall be applied to school purposes as therein provided, except whatever excess there may be after providing for the Negro and mulatto paupers in each county.

2. No part of said fund collected in the present year shall be applied, except as provided in the first section of this act.

3. This act shall be in force from its passage.

This final version, short and to the point, completely disenfranchised African-Americans, who had advocated for the tax in order to fund education of their children, and who the state now required to pay a tax that would not in any way be allocated for that purpose. The Act, drafted in vagueness and revised twice, demonstrated the extent of Kentucky's African-American citizens' willingness to sponsor their own schools. Unfortunately, the state legislature's enforcement of the law posed no threat to offenders.

By 1867 , the issue of the misappropriation of the "colored school fund" found its way into reports from the state superintendent of public instruction to the governor of Kentucky. In a report dated, 31 December 1867, Superintendent Z. F. Smith stated, in a section subtitled "Education of the Colored Population," "they have never asked anything 
from our legislators more than the enactment of a law which would collect a tax from their own scant earnings, and provide for the disbursement of the same, with certainty and economy, for the education of their children" (Legislative Document No. 18). Smith also stated that the "legislative experiments" had "inflicted great injury and injustice on this class." He summarized the radical changes in the law that I have previously discussed at length and quoted from a report of a School Commissioner who indicated that there were no colored schools in his county because trustees claimed that the offering of schools was an option, not a requirement. He closed this segment of his report stating, "I am satisfied that no experiment of schooling the colored children can be successful while the same is associated with, and made partially dependent on, a scheme for the support of paupers." He advocated for separate funds for schools and paupers.

Smith, in a combined report to the governor for the years $1870-1871$, once again criticized the impropriety of the state legislature in denying African Americans the opportunity for a funding source. "I think it is to be regretted that the dominant feeling of our legislative sentiment is adverse to the policy of educating the colored population, even though they have petitioned for nothing more than a modified and practicable law, to be taxed themselves independently for the education of their own children" (Legislative Document No. 16, 99). Smith reported on much in this text. First, the "dominant" feeling among those in the state legislature was that African Americans did not need schools, even if they were willing to pay for them. Smith's report also alluded to the persistence of African-American citizens because in 1871, more than four years after the second revision of the Act passed, they were still petitioning for a tax. In his next few lines in the report, Smith argued the impossibility of objecting "to a policy of such simple 
justice and humanity, unless the prejudice of race has seared and blunted [the] sensibilities beyond the touch of sympathy" (99). In these words, Smith appeared a true advocate of the African American. He referenced justice and humanity as sentiments that should be applied to African-American citizens, which according Deborah Brandt's definition denotes him a true "sponsor of literacy."

However, just beyond these words, in the same report, Smith appealed to a majoritarian sentiment that positioned him as one who is not so much interested in justice and humanity, as handling the problem of the Negro. "Freed and turned loose among us," he writes, "after a lifetime of abject and arbitrary servitude, they must, in some way, be digested and assimilated as an active and real element in the body politic" (99). In this statement, Smith revealed his true sentiment for the educating of African Americans. Using the word "digested" which denotes consumption, and "assimilated" which denotes change, Smith revealed the agenda of the majoritarian culture. As argued previously in this chapter, the intended design of public school was as a tool of assimilation. In 1870 , the $15^{\text {th }}$ Amendment passed, giving African-American men the right to vote. This report, written more than a year after the amendment to the constitution had been ratified, reflected yet another majoritarian sentiment, that African Americans needed schools in order to make informed decisions at the polls.

\section{Critical Race Theory}

In the text, Critical Race Theory: An Introduction, Richard Delgado and Jean Stefancic clearly define the theory and the movement. Delgado and Stefancic identify four basic tenets of the movement: 1) Racism is ordinary; it is the normal experience of most people of color in this country. 2) The system of "white-over-color ascendency" 
serves important psychic and material purposes for both working class and elite whites, and therefore, they have "little incentive to eradicate it" (7). 3) "Race and races are products of social thought and relations", a "social construction" thesis; "races are categories that society invents, manipulates, or retires when convenient" (7). 4) The experiences of people of color have a "unique voice," and the movement urges them "to apply their own unique perspectives to assess law's master narratives" (9). The fourth tenet, among other components, includes a theme "revisionist history" in which scholars offer a retelling of an historical event from the perspective of the marginalized. Delgado and Stefancic state "revisionism is often materialist in thrust, holding that to understand the zigs and zags of black, Latino, and Asian fortunes, one must look to things like profit, labor supply, international relations, and the interest of the elite whites" (20). For the purposes of this project, I offer a focus on this theme as a lens through which to evaluate the legislative discourse in Smith's reports to the governor.

Delgado and Stefancic identify Derrick Bell, professor of law at New York University, as the movement's "intellectual father figure" (5). Bell composed a number of foundational articles, the most noted of which are critiques of the Brown v. Board of Education case. In his article, "Brown v. Board of Education and the InterestConvergence Dilemma," Bell argues that the decision of the Supreme Court to "end statemandated racial segregation of public schools" was not passed because of the concern of whites about the immorality or inequality of segregation, but rather because there were self-serving interests of the white elite (policy-makers) that made the decision prudent for America at that particular time in history (524). Bell argues that the decision accomplished three goals for the United States: improved the international image of the 
country, assuaged racial rebellion and hostility among African-American World War II veterans, and would help improve the economic conditions of the South and help to move the region toward a more industrialized society.

Bell argues that blacks had been attacking the policies of segregation for more than 100 years and that before the Brown case, courts had merely determined that facilities should be made equal; therefore, he questions why "the sudden shift" away from separate but equal to desegregation. Bell theorizes that one reason for the decision was it provided "immediate credibility to America's struggle with Communist countries to win the hearts and minds of emerging third world peoples" (524). Bell claims that this argument was used by NAACP lawyers as well as the federal government, and evidence could also been found in popular media of the day. The United States of America, the most humanitarian of all nations, had a legally enforced caste system, which was perceived abroad as unattractive, even un-American. This international image had to be altered; therefore, changes in the legal policy, even if not in the local practice, were essential.

Bell also argues that fear of racial unrest associated with the disillusionment and anger experienced by African-American veterans and political activists, in particular Paul Robeson, after World War II was a concern of the United States. Soldiers risked their lives for a country that did not respect or recognize them as equal participants in the socio-economic realm and did not allow them the freedom to pursue an equal quality of life as the majority culture. Bell completes his argument with the claim that in order for the South to transition from a plantation society to a more industrialized and 
economically profitable entity, the segregated culture had to be eliminated and all people had to be allowed to participate in a free market (524-525).

Mary L. Dudziak's article “Desegregation as a Cold War Imperative” takes Bell's work to another level, examining desegregation cases and considering the cultural and political environment in which they occurred. Dudziak examines a series of amicus briefs, documents typically filed by agencies or advocacy groups, used by the Truman Administration to impress upon the Supreme Court the necessity of upholding black civil rights at home for the purpose of world peace and national security (65). Dudziak's article offers textual evidence of Bell's theoretical argument and reinforces the concept of tenet two in Critical Race Theory.

In the previous section, I argue that the passing of the $15^{\text {th }}$ Amendment had influence on Smith's final report from 1870-71, urging state legislators to allow a tax on Negroes and mulattoes for the financing of colored schools. The rationale Bell offers for the Brown v. Board of Education critique provides an analytical model for the arguments in support of Kentucky's Colored School Fund. The years 1870-71 are the last report prepared by Superintendent Z. F. Smith. Smith's style in the reports that I have cited previously was direct, but not particularly aggressive. The Superintendent who followed Smith, H.A.M. Henderson, was not so subtle. In his report to the governor in 1872, Henderson made the reasons for his support of provisions for colored schools crystal clear:

With the colored man in the possession of the ballot, there is no single argument that can be applied to the defense of the education of white citizens that does not apply with equal force to the black. A naturalized 
Guinea negro at the polls wields as much power as the most cultivated Caucasian. The premises in the argument are the same; the terms distribute themselves in like manner, and the conclusion is inevitably of like character. ... We have a great personal interest in hastening the day when every man who holds our liberties in the ward of his ballot shall give an intelligent consideration to every question upon which he may be called to vote (my emphasis). (Legislative Document No. 245 ).

Critical Race Theorists' concept of race related decisions serving the self-interests of the white elite seems more than appropriate for Kentucky educational history. The indiscretions of management of the Colored School Fund were widespread throughout the state, until of course the education of African Americans became imperative to the plans of the white elite, at which time management of the fund was refined. However, the indiscretions associated with the Colored School Fund were part of a greater problem associated with the general public school fund.

\section{Problems Establishing Public Schools for the Majority}

The debate over African-American public education and funding in the 1860s and 1870s was a mere reflection of the broader debates within Kentucky concerning the extent of, and funding for, public education for the general population. Kentucky's track record for organizing and financing public schooling had been historically unstable. In his article "Public Education" in The Kentucky Encyclopedia, Thomas D. Clark described Kentucky's educational history as having "lacked a central educational philosophy and objectives, and running through the entire fabric of its history is a thread of casualness about educational values and objectives" (744). The state of Kentucky, particularly in the 
nineteenth century, was primarily agrarian. The vast majority of citizens throughout the commonwealth did not adopt true concerns about literacy, especially formal schooling, until well into the $20^{\text {th }}$ century (Clark 746-747). Understanding this ideological framework significantly informed how one viewed the lackadaisical attitudes state and county officials harbored when considering establishing schools for the AfricanAmerican community.

The adverse attitudes and corruption surrounding the handling of funds generated by the legislative act to finance African-American public education were normalized when situated in a larger statewide arena in which issues of mismanagement had historically occurred with funds designated for the financing of public education for even the general population. After the war of 1812, there existed a nationwide movement for establishing public school systems. Kentucky lagged far behind the nationwide trend, responding nearly a decade later. Clark reported that "on December 18,1821 , the General Assembly established a literacy fund from a portion of the profits of the Bank of the Commonwealth" (745). Though a funding source was established, there was no plan developed for a central administration, a course of study, or a distribution of funds (745). The issue of public education would be brought before the general assembly many times and in many different formats over the next 20 years; however, it was not until 10 February 1845 that "the General Assembly made the office of superintendent of public instruction a state post, created a state board of education, and encouraged the organization of common schools in the counties" (Clark 745).

In the twenty year lapse in the public school plan, Kentucky had fallen victim to financial scandal in the state legislature. In 1836, during Andrew Jackson's presidential 
administration, Congress had made provisions for distributing surplus federal funds to the states. Kentucky received a reported $\$ 1,433,757$ (Clark 745). In 1845, almost a decade later, the General Assembly mandated that $\$ 1,000,000$ be placed in separate fund for financing public schools, with the earnings from school bonds to be distributed to counties. Clark reported that "the General Assembly and the governor, however, could not keep their partisan hands off the fund" (745). Legislators ordered the bonds destroyed. Though structure was now in place, it would be many years before public schooling was widespread among the general population of Kentucky, and the state's reputation for mismanaging funds would be upheld.

Surprisingly, with this history as a backdrop, African-American leaders statewide, and in particular the city of Louisville, bestowed their trust on the state legislature to manage and allocate the school tax for African Americans appropriately. Since African American leaders were not asking for charity, but rather imposing a tax on themselves, one would assume that the state legislature would have been more deliberate in the handling of the funds. However, such was not the case. African-American leaders did put their trust in the system, and the system failed them miserably.

\section{Kentucky Colored Educational Conventions}

Though African Americans seem to have trusted the system to a fault, they also continued actively pursuing literacy sponsorship themselves. One of the mediums through which they exercised agency and advocated for literacy was through assembling themselves. The African-American convention became a very powerful tool for social change. With the strategies of the Abolitionist Movement of the early to mid-nineteenth century as a model, African Americans began to organize conventions throughout the 
country, with the focus still being liberation, not the physical liberation of the previous plight, but rather liberation of the mind through education. Conventions were mechanism for creating a national voice, demonstrating unity and strength, and preparing local leaders to do the work of the national or state agenda in their respective communities. The theme of self-help dominated the nineteenth-century convention platform. Leaders were encouraged to take advantage of the resources available through the federal government and benevolence agencies, but they were also compelled to cultivate their own initiatives in conjunction with and in the absence of outside help.

In Self-Taught, Williams acknowledges the rhetoric or primary discourse of educational conventions held throughout the southern states of South Carolina, Georgia, Missouri, and Arkansas. She argues that "self-help often appeared at the forefront when the convention delegates spoke of education. Fully cognizant of the history of white suppression of black education and aware of continuing white hostility, delegates urged black people to establish their own schools and to take full advantage of educational opportunities provided by other blacks or by northern associations" (75). Likewise, Brandt acknowledges in Literacy in Americans Lives that the spirit of self-help is one that has permeated African-American culture, even to this day. Those African Americans interviewed for her study all indicated systems of self-help that impacted their literacy learning. Brandt identifies that one of her goals with the study was to "examine through the accounts of particular individuals how long-standing forms of African-American selfhelp provided avenues for literacy learning, especially when other ways were closed off' (Literacy in American Lives 108-09). The African-American convention was one way to 
rally constituents to open avenues that historically had been closed, and the state of Kentucky was supportive of that initiative.

African-American leaders statewide assembled in the first statewide meeting of the Colored Educational Convention in Lexington, KY on 22 March 1866 (Proceedings $1869,18)$. At this convention, the state legislation for the additional $\$ 2.00$ tax on "negroes and mulattos" was lauded as a tremendous accomplishment (Doyle 15). Apparently there was a second statewide colored convention held in Owensboro in 1868, as John Langston acknowledges in the speech described in more detail below. However, I have not been able to find any documentation save a cursory mention in University of Kentucky "Notable African Americans" database. Nevertheless, when three years had passed after the passing of the state law, and collected funds had not been distributed to African-American schools, a third meeting was held in Louisville at Benson's Theater. The proceedings reflected that the keynote speakers were primarily white, save one, and the convention had been co-sponsored by the Freedmen's Bureau.

The meeting began 14 July 1869 and lasted for three days. The purpose of the convention was to serve as a pep rally for education as well as an opportunity for statewide organization for African-American leaders. The Freedmen's Bureau would soon pull out, and state leaders needed to be prepared to carry on the work of administering schools. Regional and nation dignitaries were invited as guest speakers. Among the invited was Frederick Douglass, and as is customary in these venues, his regrets were read at the opening ceremony. Addressed to John H. Haywood, his letter read as follows: 
Dear Sir-I am sorry not to be able to attend the Convention proposed to be held in Louisville on the $14^{\text {th }}$, to promote the cause of education among the colored people of Kentucky.

Other occupations, connected with our common cause, make it out of my power to comply with your wishes, and compel me to decline your kind invitation.

Please present my thanks to the committee for their invitation, and my best wishes for the success of the great objects you have in view. When slavery existed, our race could exist without education; but, to-day, ignorance means for us destitution, degradation, degeneration, death, destruction.

\section{Your Friend, FREDERICK DOUGLASS (Proceedings 4-5)}

Douglass was one among other national dignitaries whose regrets were read at the opening ceremony. Judging from the eloquent, star-studded cast that was invited, the Freedmen's Bureau and the African-American leaders throughout Kentucky had high expectations for this gathering.

As previously mentioned, the keynote speakers were primarily white, and the tasks and business of the convention was handled by African-American state leaders, most of whom were from Louisville, Kentucky (see Chapter Three). There were two speeches recorded at length, one from Colonel Don Piatt, most noted for his rebellious act of issuing an order to recruit slaves in Maryland for a negro brigade, which essentially made Maryland a free state and caused Piatt to be reprimanded by President Lincoln. The other speech was delivered by the Honorable John M. Langston, a Delaware-born son of 
a slave and a Virginia plantation owner. Langston was orphaned by age five and sent to live with relatives in Ohio, where he later graduated from Oberlin College and became an outspoken abolitionist. Both men delivered speeches of encouragement, accomplishment, and equality.

\section{Educational Rhetoric}

Colonel Piatt's speech opened with his offering a definition of two kinds of literacy: "intellectual education" and "moral education" (Proceedings 1869, 9). Piatt acknowledges African-Americans' limited abilities in intellectual literacy but he touts their superiority (to other races) in moral literacy. Piatt also devoted a good portion of his speech to creating an extended metaphor for the suffering inflicting upon African Americans during slavery and the suffering associated with one's growing in Christian experience (9). He began building a description of those who have suffered as stronger than those who abuse, "The weak grow stronger under oppression, and the strong become weak in abuse of their strength. . . . Adversity carries the precious jewel in its head; prosperity engenders poison" (Proceedings 1869,9 ). He went on to say that "Slavery enervated and destroyed the master, as it built up and strengthened the slave" (10). He finished this section by likening the negroes' experience to that of Christ: "Christ taught this lesson when he came to us in a stable from among the Nazarenes, who in that day bore the same relation to the Hebrews as the negro does to us" (10).

Piatt's speech certainly reflected the rhetoric of the day. To liken the suffering of slavery to Christian suffering was to elevate the status of slaves to one that equated them to white counterparts, and though in the twenty-first-century mind it seems to in some way diminish the atrocity of slavery and assuage the guilt by association of the majority 
culture, I acknowledge that Colonel Piatt's speech was intended to build character and motivate. Piatt ultimately acknowledged in his speech that intelligence was not racebased (11), and he warned that Southern politicians would romance negroes soon to be given the right to vote (10), both of which made for good social and political advice. He ended his speech, as Williams and Brandt discuss, with a theme of self-help:

And now let me say, in conclusion, the hour approaches when the Government will have ended its work of reconstruction, and, handing you the ballot, leave you without further guardianship. You must stand alone; and what I want to say to you, and that which I want you to remember, is that if you are sure to triumph and become an important part of the republic and a feature in her future destiny, and without these no help from government or other hands can help you. (15)

As mentioned previously, the foundational discourse of nineteenth-century AfricanAmerican conventions was self-help, and literacy was the mechanism through which African Americans could position themselves for upward social mobility. Piatt's speech certainly adhered to the prescribed rhetoric that lauded African-American suffering and encouraged them to work hard and help themselves.

In contrast to Piatt's speech, John Langston's speech was not one to glorify the suffering of slavery; he spoke to the strength of African Americans during and since emancipation. He acknowledged a great celebration on 4 July 1865 , where 20,000 slaves from the suburbs of Louisville gathered in the city, "returning to their homes freemen and citizens, by reason of declaration of Gen. John M. Palmer" (18). Langston offered an eloquent recollection of the event: 
Alighting from his carriage, Gen Palmer came upon the platform in the midst of that vast crowd of people and announced in the name of the Declaration of American Independence, in the name of the Constitution of our country, in the name of American law itself, and by virtue of the instructions given him by the then President of the United States, he was authorized to declare that every man in Kentucky belonged then to himself, and thenceforth and forever was free and clothed with American citizenship. (18)

Langston went on to reference two previous Colored Educational Conventions and his honor at being invited to be present at all of these monumental expressions of liberty. The focus of Langston's speech then shifted from one of celebration to one of encouragement toward the next step-achievement.

Langston acknowledged the motto of the conference as "liberty, labor, and law" (19). He touted achievement as the great equalizer, and almost on a prophetic note (given today's circumstances), acknowledged "that if a black man is made President of the United States it is well" (19). Langston continued this segment by acknowledging the necessity of both races working "hand in hand" (19). He then took a more radical turn, asking African Americans to demand their rights, not in the spirit of their previous condition, but in the spirit of their current citizenship: "We should not be taxed and forbidden representation; made to bear the burdens of the State, and not enjoy the prosperity and the peace that comes of a social standing in the State inside the body politic" (20). He once again stated that now that slavery was abolished, African Americans were citizens and should hold the positions of state including "constable, 
marshal, Chief Justice, or President" (22). Langston identified four components used to determine social class and dictate upward mobility_-"education, culture, wealth, and character"' (22). Using Frederick Douglass as a classic example, Langston encouraged attendees to aggressively pursue advancement in these areas of life to achieve greatness and live prosperously.

Though Langston's tone was clearly celebratory and motivational, there was a strong undercurrent of assimilation in his speech as well, putting his ideology in line with that Superintendent Smith and Henderson. Langston offered narratives throughout his speech to illustrate how African Americans might achieve social mobility. One story suggested that if a colored man and a white man were given the same opportunities and functioned within the exact set of circumstances, their lives would yield the equal results (23). Another story used the illustration that if an African American desired to be a lawyer, he should be prepared to have money for books, support his wife "as a lawyer's wife should be supported" and put her inside the circle in which lawyers move, and "[he] must have the ability to make [him]self agreeable with the society in which [he] live[s]" (26-27). Langston ultimately stated that "no one can justly make the charge of ill treatment against society until he has cultivated and prepared himself for a place within its limits" (29). Though most of what Langston included in speech was celebratory of African-American accomplishment in Kentucky, celebratory of African-American achievement throughout the states, fairly radical in its encouragement and aim for the future, the ideology of the majority culture still found its way into the discourse.

Post-war and reconstructive themes of assimilation permeated the public discourse of the time. African Americans were admonished to emulate the majority and 
model their lives after the lives of the many African-American leaders who had successfully done so. These conventions served as an opportunity for African Americans to assert agency, but they also served as a venue for the majority culture to infiltrate the discourse and to ensure that the ideology of the conventions was in line with the agenda of the majority culture. Critical Race Theorists argue that the presence of the majority culture at these gatherings of African-American enrichment and organization serves their need be aware and have some degree of control in the workings and doing of the other. It seems that given circumstances where the majority culture is ever present in the public sphere, the one area of public discourse that afforded African-Americans the greatest amount of autonomy was the African-American press.

\section{The African-American Press}

One of the greatest challenges of my research has been to find representation of nineteenth-century, African-American voices in the public sphere. Lobbying for change through the state legislature and gathering in state conventions to assign numbers and voice to the presence within state were effective uses of agency in this statewide pursuit of literacy and education. Another medium through which African Americans could wield agency for social change was through the African-American newspaper. Because the state of Kentucky did not have African-American publications until the very late nineteenth and early twentieth centuries, African-American citizens throughout the state sent correspondence to periodicals outside of Louisville in order to self-report local literacy, as well as other kinds of socio-economic success. The Christian Recorder was a publication sponsored by the African Methodist Episcopal Church, headquartered in Philadelphia. It was started in its current format in 1861 and was circulated deep into the 
South through distribution to African-American union soldiers. Because it allowed for correspondence from throughout the South and West, The Christian Recorder became immensely important to African-Americans throughout the states as their representative voice, to some degree their national news source. Issue after issue consists of AfricanAmerican citizens from throughout the nation writing to report the "goings-on" in their local areas, and the citizens of Kentucky were no exception.

In an issue of The Christian Recorder dated 22 December 1866 in an article titled "Letter from Kentucky," a citizen claimed to have sent the letter "hoping that news from here abouts will be acceptable to the many friends of humanity." After acknowledging the benevolence and sobriety of Lexington's African-American community, the letter reports:

We have a public school, which opened on the $25^{\text {th }}$ of Sept., under the auspices of the American Missionary Society who furnish teachers; there are six hundred and fifty scholars in attendance; a greater number than there is in attendance at the white schools, at least, than there were at the last report. The school commissioners say that the Howard or colored school will compare favorably with any in the city.

This letter carefully praised both the majority and African-American communities for the commitment to literacy; yet, the text comparatively acknowledged the particular success of the colored school. The number of scholars in attendance indicated the level of commitment from the community, and this writer felt that was cause to celebrate. An interesting side-note on this letter, and notably several others printed in The Christian Recorder from the state of Kentucky during this time period, was that the letter was 
signed "ALEPH" and dated "Dec. 13" '66.", The individual writing this letter from Kentucky was likely seminary trained (or at least with some form of advanced education) and chose to sign these correspondences symbolically, representing a new beginning for African Americans.

\section{Self-Help as Self-Sponsorship}

The tenacity with which the state leaders pursued education and literacy is notable given the level of hostility they were up against. However, this small excerpt of a very big narrative reinforces the sentiment of strong cultural concerns about education and literacy held by African Americans throughout the state, and in particular Louisville, and to what extent they were willing to go in order to achieve it. The fact that they had lobbied for an additional state tax and were making an effort to organize themselves before the Bureau was disbanded speaks to their independence and self-help ethics. What both Williams' and Brandt's studies found to be true in other geographic locations and time periods, I have found to be true throughout the state of Kentucky. However, the city Louisville, though its history is consistent with other parts of the state, presented a unique set of circumstances that warrant examination. Though there was a nationwide push for literacy, particularly through self-sponsorship, those African Americans residing in the Louisville area, immediately following Emancipation, felt a particular sense of urgency for opening of public schools, and the African-American leaders of the community exercised their own system of self-help through serving as the chief lobbyists for the passing of legislation and being an organized agent for outcry.

\footnotetext{
${ }^{3}$ Aleph is the word that represents the first letter of Semitic alphabets and in Hebrew came to represent the number one.
} 


\section{CHAPTER THREE}

\section{Making the Case for Louisville, Kentucky: a Unique Set of Circumstances}

"The cultural landscape ... is continually implicated in the ongoing reconstitution of a discourse, or set of discourses, about social life, and it is in this sense that it serves as both a disciplinary mechanism and a potentially liberating medium for social change" (Schein 664).

\section{INTRODUCTION}

In this chapter, I offer Louisville as an historical case study and make an argument for nineteenth-century Louisville's being a unique rhetorical and discursive space. The quest for literacy and the educational opportunities in Louisville occur as a result of a unique set of historical and cultural circumstances. Though there are many histories of education of the southern states that might bear similarities to the Louisville phenomenon, borrowing from the discipline of cultural geography, I argue that Louisville has a unique cultural landscape that informs and influences the African-American population and their literacy, rhetorical, and discursive practices.

I argue that Louisville's geography influences the development of the city landscape in general and social systems within the city in particular. I examine a collaborative African-American community that includes free-born, freed, and slaves that live, work, worship, and read side by side and create a unique cultural and ethnic landscape that impacts how literacy is perceived, sought, and secured in this environment. In his text Life Behind a Veil, George C. Wright cites a 1942 article in The Courier Journal in which the author writes on the historical perspective of race relations 
in Louisville and concludes that, "By comparison with some other communities they have been almost Utopian" (2). I certainly would not attempt to make the argument that Louisville was a utopia, but I do believe the socio-cultural experience for AfricanAmericans was atypical. Using Michel Foucault's term from the speech "Of Other Spaces" (1967), I offer this unique atmosphere as a kind of "heterotopia." Foucault says that "Utopias are sites with no real place" (4). They present society in its perfected form, which of course is not real. Foucault offers the term heterotopias, in contrast to utopias, as sites of real places, which are not perfect but contain unique, real life experiences. He goes on to say that between utopias and heterotopias, "there might be a sort of mixed, joint experience, which would be a mirror" (4). I have previously referred to Louisville as a collaborative community because I believe it possesses an interesting socio-cultural "mix." The unique set of nineteenth-century circumstances that existed in AfricanAmerican Louisville might also mirror other nineteenth-century African-American communities, or it might mirror the surrounding white community, but it is certainly a cultural, literacy narrative worthy of exploration.

The Cultural Landscape Yields the Discourse Community

As will be discussed extensively in the following section, the physical landscape of Louisville is important to the growth and development of the city in the nineteenth century, and the cultural landscape that evolves is significant. In subsequent sections of this chapter, I will describe in detail the collaborative African-American community that existed while considering cross-disciplinary scholarship on material space. In recent years, more attention has been paid to the effect of material space on the human existence. Scholars in the sciences, social sciences and the humanities are considering 
that material space has just as much impact on human behavior as social environment. Richard H. Schein, citing a host of cultural geographers, argues in his article, "The Place of Landscape: A Conceptual Framework for Interpreting an American Scene" (1997), that landscape is symbolic, representative, gendered, class-based, politicized, and central to the production or reproduction of social life (660). He goes on to say that "Landscapes are seen as texts, as metaphors, and as part of discourses" (660). And Foucault tells us: This problem of the human site or living space is not simply that of knowing whether there will be enough space for men in the world ... but also that of knowing what relations of propinquity, what type of storage, circulation, marking, and classification of human elements should be adopted in a given situation in order to achieve a given end. (2)

Likewise, scholars in the field of Rhetoric and Composition have explored how rhetorical practices are influenced by space and how spaces often determine who gets to compose and the content of their compositions. Nan Johnson's Gender and Rhetorical Space in American Life, 1866-1910 (2002), explores how the "parlor" became a rhetorical space in which white women performed traditional femininity. She goes on to say that because women's words mattered in this particular space, they generally spent their time reading conduct literature. Roxanne Mountford's The Gendered Pulpit: Preaching in American Protestant Spaces (2003) considers the relationship between bodies, space, gender, and race in rhetorical performance in the Protestant culture. Mountford examines preaching manuals from the nineteenth century to the present and explores the "manliness" and "whiteness" of pulpit performance instruction, as well as the masculinity of church architecture itself. Similarly, Nedra Reynolds' work in 
Geographies of Writing: Inhabiting Places and Encountering Difference (2004) explores how people experience space and what that might tell us about how they experience other forms of the social world and the implications of such for our classrooms. Recognizing that material space does influence cultural and rhetorical practices, I argue that the nineteenth-century, African-American community in Louisville, Kentucky developed and functioned in a unique cultural landscape. This material space influenced and created an atmosphere where African Americans were free to exercise agency in social and political contexts that created educational opportunities for their community.

\section{The Geography}

The River

Several geographical characteristics make Louisville an interesting space. As a riverfront city, Louisville enjoyed a very transient population that arrived while traveling, resided in its fancy hotels, enjoyed its fabulous restaurants, and bought goods and services within the metropolitan area, which made for lucrative opportunities for entrepreneurs. Because Kentucky was a border state, and Louisville was a city bordering on freedom into Indiana and in close proximity to Ohio, there was also a very transient and often secret community of African Americans hoping to either blend in with the collaborative African-American community that existed in Louisville, or wishing to hide long enough to be able to make it to freedom in the days to come. J. Blaine Hudson refers to this dynamic as "human landscape - the numbers and locations of both enslaved African Americans and free people of color-were as important as the location of mountains, rivers, and roads" (Fugitive Slaves 13). Louisville's riverfront, border city 
status fostered an atmosphere that made for endless social possibilities for whites and African-Americans alike.

The Economy

One of the reasons for Louisville's exponential growth in the nineteenth century was its geographic location. Louisville was founded and developed right along the line and curves of the Ohio River. The Ohio River, though at times tumultuous and even dangerous, proved to be a tremendous asset, particularly for transportation of goods and services, as well as human cargo for both recreational and industrial transportation (slavery). The twenty-five foot drop over a two mile stretch of limestone came to be known as The Falls of the Ohio (Hudson Fugitive Slave 12) and made it necessary for boats to unload their cargo before attempting the Falls, as "no loaded flat or keel [boat] dared go over the Falls" (Yater 32). So Louisville's convenient location beside the Ohio River made it a inieteenth century transportation hub. Freight would be shipped by waterway to Louisville, unloaded and transported by land to various locations, which put particular goods and services in high demand within Louisville's metropolitan area. These demands spurred the metropolitan growth of Louisville and created economic opportunities for all Louisvillians, but a unique set of opportunities for both enslaved and free African Americans in Louisville.

As it is today, Louisville developed as a very urban area, so there was little demand for agricultural-type labor, but because of the rapid growth and the urban atmosphere, the demand for skilled labor and trades was abundant. Many slaveholders saw these labor demands as an opportunity to make money; consequently, the Louisville area fostered a sophisticated slave-leasing system. From as early as the 1790 s, and with 
increasing numbers in the nineteenth century, slaves were leased to perform an array of jobs, from domestic/agricultural work to highly skilled carpentry and bricklaying and just about everything in between. However, what makes the slave leasing system interesting is the number of community liberties it afforded bondsmen.

\section{The Ante-Bellum African-American Community (Free-Born, Freed, and Enslaved)} Slavery in Louisville

Despite slavery's prevalence in the state of Kentucky, the climate for slaves in the city of Louisville was a unique one. In his text A History of Blacks in Kentucky, Marion B. Lucas acknowledges that when the urban areas of the state were developing, many slaveholders who owned slaves with trade skills hired out the labor of their slaves to make a profit. Slaves were leased to perform an array of skilled labor jobs: domestic servants, agricultural workers, mechanics, railroad workers, carpenters, bricklayers, servers in restaurants and hotels, factory laborers, lumber mills laborers, etc. (Lucas 103104). However, what makes Louisville's slave-leasing system out of the ordinary is the number of community liberties it afforded bondsmen.

As a general rule, when slaves were leased to others by their slaveholders, there were extensive contracts drawn between the leaser and the leasee. These contracts usually charged those leasing slaves with the responsibility for the food, shelter, health, and clothing, as well as a monetary payment to both the slave and the slaveholder for the duration of the lease. Slaveholders with a labor surplus stood to make annually between 12 and 15 percent of the slave's total value, which could potentially yield large profits (Lucas 103). In some cases, slaves were given the liberty to lease themselves. In these contracts, slaves found and negotiated their own work and paid their slaveholders a fixed 
monthly amount during the lease period. This system changed the lives of many slaves by allowing them the opportunity to work lucrative jobs, save money for themselves, and in some cases buy their own freedom, and possibly the freedom of their relatives.

The table below offers a snapshot of Louisville from the U.S. Census in the midnineteenth century, as well as a visual of the African-American social dynamic that existed in Louisville at that time. Free people of color made up a significant percentage of the African-American population even before emancipation. Couple this statistic with the social system of permitting slaves to dwell in an urban environment, work profitable jobs, and intermingle with a free, African-American population of significant proportion, and realize that this material space, this cultural landscape, is anything but typical.

Table 3 Population of African Americans in Louisville, Kentucky 1850 and 1860

\begin{tabular}{|c|c|c|c|}
\hline & $\begin{array}{c}\text { Total African-American } \\
\text { Population }\end{array}$ & Free People of Color & Slaves \\
\hline Census 1850 & 6970 & $1538(22 \%)$ & $5432(78 \%)$ \\
\hline Census 1860 & 6820 & $1917(28 \%)$ & $4903(72 \%)$ \\
\hline
\end{tabular}

As a matter of fact, there existed some open white opposition to the way that free people of color and slaves interacted. In an article entitled "Local Evils" which appeared in the Louisville Public Advertiser dated 30 November 1835, a white citizen of Louisville reacts in this way:

We are overrun with free negroes. In certain parts of our town throngs of them may be seen at any time- and most of them have no ostensible means of obtaining a living. They lounge about through the day, and must subsist by stealing or receiving stolen articles from slaves at night. Frequently they are so bold as to occupy the side-walks in groups, and compel passengers to turn out and walk around them. Their 
impudence naturally attracts the attention of slaves, and necessarily becomes contagious. In addition to this, free negroes are teaching night schools. Slaves are their pupils and, to the extent of the tuition fees, are induced, in most instances, to rob their masters or employers. One of these schools has, we learned, been regularly filled at night, month after month, and our city's protectors seem to be, as yet, as ignorant of the fact as if they were the guardians of Constantinople.

There is another evil, and a crying one, which has thus far been perpetrated, in the teeth of the laws, and in contempt of public opinion. We refer to the permission given by owners to slaves to hire their own time. -This practice is not only injurious to those who have to hire servants, but corrupting in its tendencies.

This citizen goes on to advocate for Louisville to "eradicate" these evils. Clearly, to this citizen, and likely to others, the free population has had an impact on the enslaved population, encouraging them and participating in the furthering of education/literacy, and the slave leasing system seems to be at the hem of what this citizen feels is the problem.

On the other hand, this article also illuminates much about the African-American people the white citizen describes. In the various points of this complaint about the inappropriateness of the African Americans' behavior, both the free and enslaved people are exercising agency in social environments. The author mentions the "free negroes' " brazen attitude of congregating or being at leisure in public spaces. He complains that the free people are teaching the slaves in night school, and that the slaves have the audacity 
to attend. He even attacks slaveholders who award permission for their slaves to lease themselves. All of these scenarios demonstrate a heighten sense of independence among African-American Louisvillians.

One exceptional and unique narrative of a leased slave's entrepreneurship is that of Jim, a Louisville carpenter who began hiring himself out in 1845. Jim paid his owner \$25 monthly during the spring, summer, and fall, and \$20 monthly during the winter (provided work was available). During his leasing period, Jim was able to earn enough to purchase several houses, which he rented to hired slaves and free blacks. As the demand for work grew, Jim began to subcontract work. He placed "hired out slaves" in jobs throughout the city and took a percentage of their pay as commission. Eventually Jim's income was more than $\$ 200$ monthly. Jim's empire unraveled when one of his associates was picked up by the town patrol. The worker had forged work papers, which led to an investigation of Jim's other workers, all of whom proved to be runaway slaves. Jim did have to pay his slaveholder a large financial settlement, but he escaped prosecution and eventually was able to purchase his freedom (Lucas 107).

Jim was obviously a real exception to a general rule; however, there were others. Isaac Throgmorton worked as a barber and paid his slaveholder \$240 annually for more than 20 years. Bartlett Taylor hired himself out as a butcher and paid $\$ 300$ annually to his leaser. Though there are varying statistics because of incomplete census and tax records, scholars estimate that anywhere between 16-20 percent of Louisville's slave population was leased (Lucas 107). These experiences illustrate the unique atmosphere that existed for slaves, freed, and free people of color in the Louisville area. Because the leasing system allowed many slaves to live independent of their masters, slaves often lived in 
homes in communities where they intermingled with free blacks. This cultural landscape not only changed the realities of slaves and free African Americans, but also changed the material spaces in which they lived. In these cases, slaves, in an economic sense, controlled their own wages and accumulated wealth, and in a social sense, gained a very strong sense of community, which led to cultural concerns about religious practices and educational opportunities for themselves and their families. Lucas acknowledges why this sentiment was prevalent in the city of Louisville as well as throughout the state of Kentucky: "In contrast to states of the Deep South, Kentucky did not prohibit by law the education of slaves, though scattered white opposition existed to the idea of literate bondsmen" (140). Not only did Kentucky not have laws against educating blacks, regardless of their status, several white religious denominations in Kentucky advocated for the education of slaves for "religious and humanitarian purposes" (Lucas 140). With religious organizations being at the forefront advocating for African-American education, the black church, often initially sponsored by white organizations, became the hub for educational opportunities.

Ante-Bellum African-American Churches

Historically, the African-American church has been the most important institution in shaping the cultural landscape of its community, and Louisville was no exception. Just as there were several African-American schools functioning before emancipation (most of which were housed in churches), so were there several independent African-American churches. Traditionally, African-Americans, both free and enslaved, attended churches along with their white counterparts and sat in balconies as reminders of their station in life. Most African-Americans remained members of white churches until after the Civil 
War, but those who could do so, formed all black churches. Separate churches generally arose when blacks became a sufficiently large portion of the white congregation. In most cases, the mother church established a committee of whites to oversee the black church and attempt to maintain some level of control. Louisville's first African-American church began worshipping as a separate entity as early as 1839 , under the direction Reverend Henry Adams. He arrived in Louisville in 1829 as an ordained Baptist preacher. He became the pastor for black members of First Baptist Church. In 1839, the congregation worshiped in a separate facility, which they constructed, and were paying Adams an annual salary of $\$ 500$. In 1842 , they separated from First Baptist and formed the First Colored Baptist Church, (later known as the Fifth Street Baptist Church), but maintained congenial relations with the mother church. Fifth Street Baptist Church, still an active congregation, occupies a facility on Jefferson Street in Louisville today. The Second Colored Baptist Church began as a mission in First Baptist Church. In 1839, a small group of approximately twenty-five, led by George Wells, began meeting in a house on $5^{\text {th }}$ Street. By 1844 , they were granted permission by First Baptist to start the Second Colored Baptist Church (later known as Green Street Baptist Church). Wells pastored the church until his death in 1850 , at which time the church had 300 members on the roster (Lucas 123-126).

African Americans also actively participated in Louisville's Methodist churches. By the 1830s, black members outnumbered white members in the Methodist church. In 1831, Center Street Methodist Church began conducting separate services. In 1845, the white Methodists attempted to regain control over the congregation, but the church ultimately seceded from the Methodist Episcopal Church and became members of the 
African Methodist Episcopal Church. Likewise, Quinn Chapel, with its humble beginnings in a barn in 1840, moved to a partially finished brick building in 1854 and worshipped in the basement for four years until the sanctuary was complete. Fourth Street Methodist Church (later known as Asbury Chapel) was the most controversial congregation. The church structure was leased by white Methodists in 1842. In 1845, James Harper, a free black, Methodist minister, purchased the facility for his congregation. When Harper attempted to leave the Methodist Episcopal Church after the national church's split into northern and southern branches, and join the African Methodist Episcopal Church, a heated confrontation between blacks and whites ensued in the sanctuary. Whites claimed that the blacks could leave the southern branch, but they could not take the church property. A court battle in 1849 decided in favor of the AfricanAmerican congregation (Lucas 128).

Though all five of these narratives of spiritual independence are profound, the Asbury Chapel court battle is exceptionally so. It demonstrates that Louisville, Kentucky was a nineteenth-century space, with legalized and enforced slavery, in which a congregation of free and enslaved blacks won a court battle over property against white evangelicals. This act is exceptional because it not only illustrates the tenacity of the black community but also demonstrates the evolving political landscape of the Louisville community as a whole.

Ante-Bellum African-American Schools

Just as the church created a space of independence in the African-American community, so did the school. The slave leasing system in the city of Louisville allowed many slaves and free African Americans to be financially stable enough to provide 
education for their children in private settings. Consequently, even before the Civil War and Emancipation, a select number of black children in Louisville were openly receiving schooling, primarily in facilities housed in and sponsored by churches. Ruby Wilkins Doyle offers a catalogue of these schools in Recalling the Record. One such school came to be known as the Adams School. The Adams School opened December 1841 on Woods Alley between Ninth and Tenth Streets with 5 pupils and the Reverend Henry Adams as school teacher (Doyle 8). Several other small private schools would follow: one by W.H. Gibson in 1847 on Green Street west of Fourth; another by him in 1866 at Quinn Chapel AME Church located on Walnut (currently Muhammad Ali Blvd.) between Eighth and Ninth Streets and then later between Ninth and Tenth; one by Henry Henderson in Center Street Church; one by Aunt Pendy, Reverend Brooks, and Jessie Davis on Baptist Row, now part of Madison Street; and in 1869, Reverend W.W. Taylor conducted an eleemosynary school, one that functioned completely on charitable donations, at his home located on the same square with teachers Mary A. Johnson, Mrs. Barnett, Hallie Roberts, and Miss Fisher (Doyle 8-9). These schools functioned through private donations and tuition, pre- and post-emancipation, and helped to forge the discourse community that would develop from this unique cultural landscape. Wartime Louisville

The function of the city of Louisville during the Civil War forever changes the cultural landscape of Louisville's African-American community. In the beginning of the war, the climate in Kentucky was one of neutrality, while acknowledging its kindred relationship with the South. Trade with the South was a booming industry, and Louisville was at the center of that trade activity. However, in September 1861, the neutrality gave 
way; Kentucky did not want to secede and therefore joined forces with the union, primarily because the state sold Kentucky products to the Federal Army (Wilson 8). Therefore, aligning with the union made good economic sense even if it was idealistically in contrast with the average white citizens' beliefs.

Louisville became the military headquarters for the state and received a large percentage of the contracts; products for which there was a high demand included tobacco, whiskey, and pork packing. Though African Americans were not permitted to enlist in the early stages of the war, their labor freed white men for military service (Wilson 8). However, with a steady increase of Union activity in the city, it became increasingly difficult to separate wartime activity from African Americans, both free and enslaved, living within the boundaries of Louisville. Northern union troops streamed into Louisville because it housed thousands of troops and had a vast supply and munitions depot. Much of the Union military activity became radical. Northern troops from various states violated Kentucky Slave Law: "Slaves were confiscated by troops, allowed to join various regiments, harbored and provided with army employment" (Cummings and Price 2).

Nevertheless, Kentucky slaves were not officially permitted to join the army until May 1864 , when the $107^{\text {th }}$ Regiment Infantry Corps d'Afrique was formed in Louisville. Later that year, the $108^{\text {th }}, 109^{\text {th }}, 122^{\text {nd }}$, and $123^{\text {rd }}$ were added, and the $125^{\text {th }}$ in February 1865. These regiments were formed in Louisville, but the African-American soldiers who occupied them were not exclusively Louisvillians. They were fugitive slaves from other parts of Kentucky and other southern states who sought the protection of the Union soldiers. On March 3, 1865, this migration was heightened when Congress enacted 
legislation which made the wives and children of enlistees unconditionally free. Slaves were given freedom, $\$ 400$, and a thirty-day furlough to move their families in exchange for enlistment and service (Wilson 11). Many slaves passed through Louisville as a result of this initiative, and some never left. The total number of African-Americans in the city of Louisville increased markedly from $1860-1870$, from 6,820 to 14,956 respectively. This migration caused a significant increase to an African-American community which had proven independent and self-motivated. This influx of former slaves abandoning the Deep South more than doubled the population in this cultural and geographical space of progressive African Americans.

\section{African-American Leaders}

Because of the pre- and post-war cultural landscape that existed in Louisville, the African-American leadership of Louisville, by proxy, became the African American leadership for the state of Kentucky. As discussed in Chapter 2, slavery in Kentucky was not officially abolished until the passing of the $13^{\text {th }}$ Amendment in December 1865 . As a result of this legislative document and formulation of the Freedmen's Bureau, AfricanAmerican leaders throughout the state of Kentucky organized to advocate for public schooling for their children. In February 1866, the General Assembly of the Commonwealth of Kentucky passed the first "Act for the Benefit of the Negroes and Mulattos in this Commonwealth." Though this legislative act would undergo a radical transformation and ultimately become irrelevant (see Chapter Two), it demonstrates the tenacity of the African-American leadership within the state, most of whom resided in Louisville. 
Because this law was not being honored by municipal and state officers (see Chapter Two), the African-American leadership of the state convened in a statewide Colored Convention in Lexington in March 1866 (Howard 307). Though I have been unable to locate proceedings from this meeting, the Louisville Daily Courier 28 March 1866 reports of the bitter opposition of whites to the gathering and the "Declaration of Sentiments" by African-American leaders to help the African-American masses understand the necessity of education (Howard 307). African-American state leaders were aggressively pursuing state funding for African-American schools, and the Freedmen's Bureau as well as other benevolent organizations were actively working to establish schools throughout the state and to provide protection for those willing to teach and learn in these facilities. Understanding that the Bureau would not always be available and recognizing that the state legislature had not been successful in managing allocated funds, the African-American leadership of Kentucky and the Kentucky Leadership of the Freedmen's Bureau convened a second state convention, "The Kentucky State Colored Educational Convention" at Benson Theater in Louisville. This meeting was held to organize the African-American leadership of the state. When the Officers of the State Board of Education were elected, the offices of president, vice president, secretary, and treasurer were all held by community leaders in Louisville: William H. Gibson, Q. B. Jones, Jesse Davis, and John Morris, Sr. respectively. Though all but one of the speakers of the general sessions were white representatives of the Freedmen's Bureau, most logistical and governing responsibilities were performed overwhelmingly by AfricanAmerican Louisvillians. Likewise, the "Committee on Permanent Organization" contained seven of sixteen members from Louisville, and the convention had twenty- 
three delegates from the city of Louisville. It is evident that the African-American leadership was taking a very active role in statewide educational initiatives (Kentucky State Colored Convention 1869 Proceedings).

\section{Exercises in Agency and Absence}

As mentioned in Chapter Two, the acts of lobbying state legislators, gathering at state conventions, and utilizing the African American press were ways that African Americans exercised agency and brought about social change. Though I have written of the persistence of the African-American community in Louisville, I have struggled with my inability to locate its voice in this historic quest. Many secondary sources laud the work of Louisville's nineteenth-century African-American leaders, but their words have not been recorded or preserved in the annals of history. This deficit in research has likely occurred because I have limited my analysis to public discourse, and as I argued in the beginning of this chapter, material space is significant in determining which group has voice and also who has an opportunity to use it in a given space. Though the AfricanAmerican voice is essentially absent in Louisville's public discourse, African-American Louisvillians, like those in other parts of Kentucky, were also able to find agency outside their immediate public sphere via the support and utilization of print media.

Like the rest of the state, Louisville, Kentucky would not be able to boast of an AfricanAmerican publication until the early $20^{\text {th }}$ century. However, they did not allow that small limitation to deter them from getting the word out about their achievements as well as their barriers, both in and out of the local community.

As mentioned in Chapter Two, The Christian Record served as a sounding board for African Americans far and wide. On 3 June 1865, a Letter to the Editor, entitled 
"Letter from Louisville," was published in The Christian Recorder and signed by T. Strothers. Included in the letter were a number of positive happenings, as slavery had been abolished and the African-American community was transitioning. However, what was most intriguing about this letter was the report on the success of local schools:

Our schools are doing well, every thing considered. I saw a report of the colored schools in this city, by the committee of the National Freedmen's Relief Association, who visited this city in the early part of April last, which I consider very imperfect. The report says: "There are eleven colored schools in Louisville, such as they are, taught by incompetent teachers." We would like to know how this committee could report upon the quality of the schools or the teachers without visiting them? There is a school taught by J.H.Cook, a graduate from Oberlin, Ohio at Quinn Chapel, on Walnut street, between Eighth and Ninth streets, which now numbers over one hundred scholars, which is certainly managed splendidly, by Mr. Cook and his assistants. ... [T]he Rev. Henry Adams, who has taught in this city for the last twenty or more years with great success, is still conducting two day-schools, which are both doing well, being conducted with good order.

Strothers used the newspaper as a medium to channel his frustration as well as challenge the majority culture about the report of the Freedmen's commission. He wanted to report the success of local African-American educators' efforts for literacy. He wanted to discredit any report that would tarnish the educational tradition that was self-directed and longstanding. 
In Chapter One, I introduced the concept of African Americans' self-sponsorship of literacy. In this regard, the African-American newspaper becomes a medium through which to exercise agency as well as a component of literacy self-sponsorship. Charles A. Simmons, in his book The African American Press, describes the role that the newspapers played in post-emancipation, African-American lives:

Since no other organized effort had been established before the end of the war for race members, the Afr[ican]-American press with its role of educator and restorer of racial identity shifted to yet another new and totally different challenge. In addition to publishing survival techniques, it made greater efforts to educate the masses by arousing, informing, and mobilizing them. Yet it never relinquished its unified role of protest. (16) Many articles in The Christian Record were reported in the above format from various cities throughout the states. Writers gave a report card - announcing success stories and special events and sounding off about injustices and failures. The black press and the organized agencies for change are some of the early methods used to put African Americans on a path to literacy acquisition and formal schooling. Though focusing on the African-American, feel-good narrative of tenacity and fortitude make for good storytelling, there is a dark-side to this tale.

\section{Competing Discourses}

In the nineteenth century, African-American public discourse is limited to "colored" conventions (in which only the most-noted African-American voices are heard as the representative voice of all), black-owned periodical press, and the publication of 
the personal narrative (which is outside the scope of this study). Yet, as certainly was expected, the true "public" discourse resides with those who control the public sphere.

When examining the articles in The Christian Recorder, the reporting on AfricanAmerican affairs has a tone of pride, self-worth, and occasionally, a defensive tone is taken in response to disagreeable incidents and social and political injustices. This tone is one not shared by the majority culture. When the Louisville Courier-Journal reported on "The Colored Educational Convention" on 15 July 1869, the coverage resembled that of a circus sideshow:

Yesterday was a grand day for the Colored people of Louisville. About noon they commenced, all ages, sizes, and colors, to gather at the corner of Fourth and Jefferson Streets. As the hour of two o'clock drew nigh, the crowd swelled larger and larger, until all four corners were covered with blacks, dressed in their Sunday attire. As they stood upon the street under torrid rays of sun, their black faces presented the appearance of an immense audience in tears, for the sweat was flowing off them profusely. Clearly this passage makes a mockery of the physical appearances of the AfricanAmerican citizens and undermines the work that the convention is intended to do.

Another event that received a significant amount of newspaper coverage was the opening of Ealy Normal School, an institution funded primarily through the federal dollars from The Freedmen's Bureau and the American Missionary Association, as well as other northern benefactors. The Louisville Daily Journal printed the speeches from the dedication at length, as told through the narrative of the reporter, on 7 April 1868, as this event was culturally significant in the African-American community and financially 
significant in the majority community. Once again, all of the speakers are influential white men from local and regional communities. I have included some excerpts herein to demonstrate tone of each dignitary's speech. These were the words of encouragement rendered to the African-American masses excited about the new school and the opportunity to learn:

You (the Blacks) have lived here an hundred years or more: you have had churches, halls, and other institutions, but until recently you have had no schools. The spirit forbade that; but the days of slavery are numbered, and you have met today to dedicate this beautiful schoolhouse, erected by the Government, not for any particular denomination, but for the freedmen of Louisville — where the children of your own race may be educated by teachers of their own color. ... Many of our teachers in the South write to us that of all the children they have ever taught none excel in aptitude and diligence of study [more than] those of the colored freedmen. - Rev. D.K. Noble, Superintendent of Freedmen's Schools in Kentucky ... thirty millions of loyal people [are your] friends. This beautiful edifice has been erected by a munificent government. Although you are not white as the Pilgrim fathers were, nor of Anglo-Saxon blood, you will achieve as great blessings for yourself and posterity if you but learn to labor and to wait. I don't believe that human greatness depends on the color of one's skin, the annals of nations and the pages of history tell a different story 
and point to a different conclusion.-Colonel Ben P. Runkle, Chief Superintendent of the Freedmen's Bureau

I will tell you that you have been in darkness. There is one important problem for you to solve, and that is to remove the prejudice now existing against you. Show your former masters, by your conduct and your acts that you are not what they think you. ... They say you are ignorant.... But you must become intelligent as well as free. I am not one of those in Kentucky who demand for you the right to vote, to sit as jurors, judges, and legislators. You must wait until a brighter day dawns upon you. Colonel I. L. Catlin, Officer of Freedmen's Bureau

I have always deemed the colored people of Kentucky the most intelligent peasantry in our country, except in portions Virginia.-Right Reverend B. T. Smith, Episcopal Bishop of Kentucky

It is of no avail to dedicate a school building unless the scholars dedicate themselves to work. Walls are nothing - hearts are all. See to it, children, that you dedicate yourselves to the work of education. Show that you are grateful to your kind friends and to our dear Government, which oppresses none but stretches out its arms in benediction to all. Improve your golden opportunity, aid your teachers, and build up and sustain your school.Rev. J. H. Heywood, Unitarian Church 
I was today gratified and partially mortified, to learn that this building had been erected by the government; a fact I never knew before. You should feel grateful to your friends and the government for such a structure, and to our glorious Congress that furnished the money with which to put it up.-Judge Bland Ballard

When you were slaves, you had no thought of the morrow. All the duties of a common manhood and womanhood devolve upon you now. You must look to them. They are responsible duties. Be earnest in labor and honest in conduct. Go to work; educate your minds and morals; work with your hands; tell all men that you have God-given rights and are resolved to maintain them. This is the gravest responsibility.-Honorable James Speed (Louisville Daily Journal, April 7,1868).

I group these excerpts because there are simply reproductions of a unified message. This message was reflective of those included in the superintendents' reports and convention speeches in Chapter Two- one of reproof and admonition. Prove that you are not ignorant; prove that you are honest and good; work with your hands; be patient for your rights, they will come when you have proven yourself; you have been called the fastest learning people ever, and we are all amazed; continue to strive, and change will eventually come, and above all, be very, very grateful for this gift, this undeserved gift, of education that you have been given. 


\section{A Commitment to Literacy in Louisville}

Historic documents reflect the sense of urgency for literacy that existed among African-Americans in the nineteenth century (see Chapter One). Amid the insults and admonitions, despite the opposition, despite the misuse of the colored school fund, despite the building burnings in the county areas, African Americans in Louisville were steadfast. In the interim time when taxes were being collected for the Colored School Fund, but funds were not being allocated for schools (see Chapter Two), Louisville private schools continued to function, and the Freedmen's Bureau continued to aide and establish schools throughout the city of Louisville.

African-American Public Schools: The End of a Long Battle

By January 1868 , the legislative act to fund schools had unraveled. Despite this obvious display of corruption, African-American leaders in the Louisville area went before the city school board urging the establishment of publicly supported schools for blacks. In March 1870, the city of Louisville adopted a new charter creating separate funds for black and white schools. The Louisville School Board appointed a "Committee on Colored Schools" to oversee the new charter. The committee offered the following report to the Louisville School Board Meeting on 22 September 1870:

To the Board of Trustees:

Gentlemen: Your committee on Colored Schools respectfully reports, that to the best information they have been able to get, the amount of the City School taxes paid and to be paid by the people of the African race in this City, for the years $1866,{ }^{\prime} 67,{ }^{\prime} 68$, ' 69 , and ' 70 is $\$ 3,659.32$ which together with the $\$ 729.53$ due to the colored people from the State 
amounting to $\$ 4,628.85$, we recommend this shall be placed to the credit of the colored school fund.

We recommend that on the $1^{\text {st }}$ of October, two schools for the colored people shall be opened; one in the Center Street African Methodist Church; and the other in the Fifth Street African Baptist Church; and as soon thereafter as a suitable place can be obtained, another school shall be opened making three in all, that in each one of these schools three teachers shall be employed; one, who shall be principal at a salary of $\$ 40.00$ per month, one other at $\$ 30.00$ and the other at $\$ 25.00$ and that toward defraying expenses of these schools for this school year, $\$ 3,500$ be appropriated.

Though this allocation was instrumental in the opening of three elementary schools in 1870 , this help was short lived. The system established by the city charter was inconsistent and did not allow for adequate funds to manage African-American schools. By 1873 , the patience of the African-American leaders had worn thin. Lucas describes the situation in this way:

During the years $1870-74$, as blacks struggled almost alone to educate their children, the call for a system of public education grew stronger. In January 1873 , a delegation of black educational leaders met with the superintendent of public instruction to urge support for public schools. A series of regional educational conventions in 1873 and 1874 called upon the legislature to establish equal schools for the state's blacks. By the end of 1873 , black leaders made it apparent that if the legislature which 
assembled in February 1874 did not create a system of public schools, they intended to force the issue through state and federal courts. (254) Responding to the pressure of African-American leaders statewide, the state legislature created a separate but unequal system for African-American students. The funding for the system came from property taxes paid by African Americans, a one-dollar tax on males over the age of twenty-one, and all fees, fines and forfeitures assessed on African Americans. Additionally, this system allowed for three African-American trustees to be appointed per district, though their power was minimal (Lucas 255).

\section{The Climate and Structure for Cultural Interaction}

The road to public education for African-Americans in Louisville, Kentucky was a long one, and even though from beginning to end, they were willing to foot their own bill, they encountered nearly a decade of fighting legislative barriers and majoritarian obstacles. Some white politicians could not understand why the state and local government were not more cooperative (see Chapter Two). In Life Behind a Veil, Wright argues that the relationship that existed between Louisville's black leadership and leading white citizens was one of paternalism; often white community leaders referred to themselves as "friends of the Negro" (2-3). Wright goes on to argue that white leaders were against federal civil rights legislation and constitutional amendments granting the rights of citizenry to African Americans, and these prominent white citizens felt that without their guidance, "Negroes would retrogress back to their barbaric African ways of life" (Wright 2). Nevertheless, African-American leaders wanted to keep race relations amicable. Wright cites various examples of leaders in Louisville's African-American community corresponding with Booker T. Washington, seeking advice on how to interact 
effectively with white citizenry, especially when raising money for specialized programs. Possibly this paternalistic interaction between the white and black leadership led to blind trust on behalf of the black leadership, and ultimately led to several years of financial corruption with public school funds.

J. Blaine Hudson takes this discussion a step further in his article "The Establishment of Louisville Municipal College: A Case Study in Racial Conflict and Compromise." Hudson describes the post-Civil War and early twentieth century AfricanAmerican leadership as essentially two different philosophical groups: the mature, passive conservatives and the young, aggressive radicals (112). Hudson goes on to say that white community leaders generally preferred to deal with the "old guard." However, Hudson also asserts that "because the city's Black population was enfranchised, politically astute, increasingly assertive, and reasonably well-organized, they often exerted considerable influence and were able to force some compromises" (113). As previously mentioned, African Americans in Louisville were proactive in establishing private schools for the education of their youth, as early as 1841 . Though they had put faith and confidence in the legislative system, they continued educating their youth in private settings during the years of financial scandal.

The dynamic of the race relations that existed between the African American and white populations of Louisville was a complicated one. African Americans as well as whites were interested in keeping relations amicable, but neither was willing to relinquish complete control over social issues to the other. Whites were willing to be benevolent as long as blacks were passive. Blacks were willing to accept benevolence, but wanted to maintain an active voice in the issues. The rhetorical dynamic left the responsibility for 
literacy uncertain. Certainly the African-American community had a great sense of urgency, which their white counterparts did not necessarily share. This sense of urgency led them to make dire financial sacrifices to achieve their ultimate goal. Whites were not eager to enforce a law for blacks that had yet to be effectively enforced for whites (see Chapter 2). So there existed a dance of negotiation between the two groups for seventeen years, until 1882 when the state passed a law allocating state support of AfricanAmerican schools.

\section{CONCLUSION}

The story of African-American literacy in nineteenth-century Louisville was a difficult one to construct. Though I have discussed in this chapter the ways AfricanAmerican citizens of Louisville exercised agency in order to bring socio-cultural and political changes in their community, I have been surprised at the absence of primary sources with representation of African-American voices. There are various documents composed by the majority culture which give accounts of African-American activity and behavior in the pursuit of literacy, but efforts at preservation of African-American words have been limited.

During the course of my research, in a discussion with Dr. David Anderson, University of Louisville, I communicated my frustration with the limited recorded history of African-American Louisvillians. Anderson responded that it was not uncommon to find a lull in literature in various periods of unrest throughout history; African Americans "were too busy making history to record it" (interview). In her text, The Afro-American Periodical Press 1838-1909, Penelope L. Bullock reports that African-American periodicals experience periods of "dormancy" due to changing cultural climates and 
political agendas (14). Phillip Blackmon in his dissertation research discusses extensively the limited resources of black-owned print media (97). I found all of these statements to be true. Studying marginalized groups and struggling with the absence of primary information often becomes a question of limited resources. Because agencies were not necessarily committed to the preservation of African-American histories, the documents that were spared likely belonged to individuals' personal papers. Sometimes family members have later donated them to museums, libraries, and archives, but oftentimes they are lost. 


\section{CHAPTER FOUR}

\section{That was Then, This is Now: Implications of a Historical Case Study}

"In order to assert and maintain their rank as men, [African Americans ] must speak for themselves; no outside tongue, however gifted with eloquence, can tell their story; no outside eye, however penetrating can see their wants." - Thomas Hamilton, Anglo-African Magazine, January 1859

\section{History Meets Modernity}

In a letter addressed to General Oliver Otis Howard, commissioner of the

Freedmen's Bureau from 1865-1874, J. B. Ramsdell gave "a detailed account of his visits through several towns in Kentucky and incidents of violence against the negroes in those places [and] of threats against his own personal safety on account of his sympathies with the negroes \& of his business in those places" (outside cover). Ramsdell, an ordained minister in the Episcopal Church and a worker in the Kentucky Office of the Freedmen's Bureau, embarked on an excursion that took him through several rural areas in Kentucky during the months of November and December in 1867. He narrated experiences so ridiculous, they almost seemed comical. However, in my role as researcher and in a moment of reflection about my own personal experiences, I realized that these incidents are not a joke, but real and significant experiences that illustrated from an eye-witness, majoritarian view, the very essence and foundation of racism.

Ramsdell traveled throughout the state with the charge to ascertain the climate of and recruit workers for establishing colored schools. Ramsdell's extensive letter gave an account of several places, but the Taylorsville/Spencer County report struck a chord with me because of a personal experience. He arrived in Spencer County on Saturday 14 
December [1867] and described the county as one where many guerillas ${ }^{4}$ resided. On Sunday morning, Ramsdell met Jasper Cox, Clerk of the Court, and asked for an "interview" the following morning. Cox naturally inquired about the nature of Ramsdell's business to which Ramsdell responds, "to see if a Color School could be established" (6). Cox agreed to confer with Ramsdell "on the morrow" but cautioned him that "the subject would have to be handled delicately in that place as most of the people would be violently opposed to such a thing" (6). The gentlemen parted, and Ramsdell retired to his room.

Ramsdell concluded that the two must have been overheard because at about two o'clock in the afternoon, a number of men converged on the tavern where Ramsdell resided. Ramsdell described hearing "loud talking and swearing." The landlord escorted a man to Ramsdell's room, who asked if Ramsdell might join him for a drink. Ramsdell, an ordained minister and a perceptive individual, declined, but the gentleman insisted, so much so that the two tussled until Ramsdell managed to run the man away with the threat of his cane (7). Ramsdell managed to sneak out of the tavern and escaped to Jasper Cox's house. Cox promised Ramsdell protection and told him to remain in the house. Cox left and when he returned, he informed Ramsdell that he had called the sheriff, the mob had dispersed, and he could safely return to his room. The landlord at the tavern, in order to protect Ramsdell, "shut up his house and locked and barred the doors, and refused to let any one in" (8).

\footnotetext{
${ }^{4}$ The concept of guerilla warfare in the Civil War, a phenomenon that mostly occurs in border states, consisted of private citizens taking up arms against those who opposed their viewssometimes other private citizens and sometimes opposing enemy troops. These incidents, characterized by bushwhacking, murder, assault and terrorism, frequently occurred, particularly in rural areas (Harrison and Klotter 204-205).
} 
Ramsdell planned to leave Taylorsville and to visit Bardstown but "was strongly urged not to attempt it, as a remnant of one of the Guerilla bands were living in the way that [he] should travel and that they would all know [him] for the agent of the Bureau" (8). For obvious reasons, Ramsdell took a stage to Louisville instead and reflected on what might have happened:

I will now state that I think Mr. Cox was perhaps the means of saving me from violence, and I must also say that my host did everything he could to insure my safety. And [to] make me comfortable he sat in with me till a late hour and in the morning went out and engaged my passage on the Coach, kept me in until the Coach was driven to the door of the Tavern[.]

Ramsdell wrote this letter in an official capacity, as a summons for peace-keeping assistance. The occurrences in Spencer County represented one incident in a narrative that gave numerous accounts of the similar stories.

In the fall of 2007, I too had a Spencer County experience. My son played a little league football game on a Saturday afternoon. Parents who have spent any time in the little league experience can attest to the fact that, at times, they can be very scary places. However, my scary experience occurred in a place that was quite a distance from the little league field. When I arrived in Spencer County, I did so in the midst of a very long, local parade. Concerned about arriving at the field on time, I decided to park my vehicle and walk with my sons to the field. I pulled into a fairly large plaza or mini-mall to park my car, as it appeared that many other parade goers or other little league parents had done. My sons and I exited the vehicle and began the ritual of gathering the necessary supplies 
(shoulder pads, helmet, bag chairs, purse, etc.). A man from a local establishment came out and across the lot to inform me that I could not park there. Confused by the presence of so many other vehicles, I inquired why-his response, "Because I said you cain't." I dug in my heels, as I am known to do, and informed him that he did not own this lot and could not deny me parking. He then said, "Leave it thar if you wanna, but you'll be sorry!" My inclination to challenge him gave way to the fear in the eyes of my twelve, sixteen, and seventeen year-old sons. My oldest was the voice of conformity, "Come on Mom. Let's just move it!"

I stood there for a minute, glaring at the man, but because my sons had not been accustomed to these kinds of battles, also because at that time, I had a very new, very nice vehicle, I turned, reloaded the vehicle and moved to a different lot, not terribly far away. One would think that this incident ended a very bad story, but not so, during our walk through the parade area to the little league field, children on the floats, who I am sure were given instructions to throw candy into the audience, began hurling them directly at my son in the opponents' uniform. I was furious, and he was scared, but we arrived at the field unharmed. Fortunately, after the game, one of the coaches drove us back to the vehicle, as the parade had ended, and he was fortunate to have his car inside the field area. We found my vehicle perfectly intact, but the incident has become one of those defining moments in our family's experience that often finds its way into humorous retellings and cultural discussions.

I share that personal narrative to say, 140 years after Ramsdell's visit, I experienced hostility in that same space. One could certainly make the argument that I experienced a hostility of another sort. No one uttered racial slurs in my presence. I will 
never know why the man refused to allow me to park in an area for which he had no authority, or why he made me feel he would do harm to my vehicle. However, my son was one of two African-American children on his football team, and no AfricanAmericans played on the Spencer County team that season. Similar to Ramsdell, my son, once safely in the car and well on his way back to Louisville, shared stories of many utterances of racial slurs, under breath, on the ball field. My son's coach, also AfricanAmerican, used this incident as a teachable moment for my son and his. He told them to use it as fuel, don't say anything, just run all over them, and that was exactly what they did. Our team won more than one victory that day, and my sons had a very realistic life experience.

This incident can certainly be interpreted as one that attests to my personal acquisition of literacy and the many socio-economic benefits gleaned from this pursuit. Clearly, Ramsdell experienced hostility because of his mission to establish AfricanAmerican schools in rural areas in Kentucky. I likely experienced hostility because of what education has allowed me to achieve and what it has allowed me to pass on to my sons. For whatever reason, the Spencer County incidents and projects like them warrant our exploration because they allow us to contribute pieces to a very large and complicated puzzle. Researchers have a responsibility to deconstruct prejudices based on untruths and not to allow leftover baggage from slavery to mar progress. My perception is that what happened in Spencer County was based on fear-fear of the truth and of the progress made by African Americans. We can only hope that future research will allow the truth to slowly erode such prejudice and fears. 


\section{Conclusions}

This project opens with a quotation from Richard Delgado and Jean Stefancic, "Revisionist history reexamines America's historical record, replacing comforting majoritarian interpretations of events with ones that square more accurately with minorities' experiences" (20). Ramsdell's and my stories present a historic and a contemporary alternative to a master narrative that touts racism is dead, that racial harmony exists, that revisionist histories only serve to rehash dead arguments, and that scholars should move away from retelling historical narratives. Revisionist histories allow us to evaluate historical phenomena, to acknowledge the damage, and work to prevent repetition. This revisionist history tells a cultural literacy narrative about an unusual, collaborative, nineteenth-century, African-American community, with a unique set of geographical circumstances that brought socio-cultural and political changes through exercises in agency by the means available in their discursive space.

This study shares the narrative of the African-American pursuit of literacy in nineteenth-century Louisville, Kentucky. The nineteenth century proved to be a period of substantial transformation for the African-American citizen. For more than two centuries, the institution of slavery had brutalized and dehumanized African Americans. As many slave narratives have substantiated, acquiring literacy became a secret passion for many. Literacy, they believed, liberated the mind, and many slaves felt that was the beginning of liberating the body. Literacy enabled slaves to better negotiate their environment and strategize to secure freedom. The abolitionist movement, among other things, posited the North against the South, and ultimately a civil war erupted. The Civil War, though on 
record as the bloodiest American conflict, served as the catalyst that ended slavery and set African-Americans citizens on a new course-an open and fervent pursuit of literacy.

After the Civil War, African Americans sought literacy with a sense of urgency. For African Americans, literacy became the vehicle that would transport them to a higher social status. African Americans viewed literacy as a means by which to gain political, economic and social progress. Though slaves had been freed, the status of African Americans had not altered. Many were not prepared to perform intellectual work. In order to rise above servitude and manual labor, African Americans understood the need to commit to literacy learning. The demand for African-American schools for students of all ages increased substantially, and the Freedmen's Bureau, African-American communities, and other humanitarian agencies established schools throughout the south.

Though the state of Kentucky passed legislation to establish an independent tax on African-Americans, which was designed to serve as a funding source for AfricanAmerican schools, the state and African-American citizens would battle over this issue for a number of years. African-American leaders in Louisville would be at the very core of this battle. These leaders and the citizens they represent offered a unique snapshot of the cultural dynamic that existed in nineteenth-century Louisville. These leaders demonstrated how exercising agency through self-sponsorship, utilization of Bureau resources, legislative lobbying, and newspaper reporting brought socio-cultural and political change.

\section{Implications}

Historiography is a controversial scholarly pursuit at best. Some scholars argue against methods of research often employed by researchers who eagerly recover, 
discover, or retrieve valuable materials and facts. Though archives, attics, and basements contain valuable information about marginalized peoples that warrant exploration, researchers must adhere to an ethical code when attempting to compose a narrative. Most researchers reveal that in their recovery effort, they are not so much attempting to get at some universal truth, but rather interested in complicating the postmodern "grand narrative." Royster and Williams argue the necessity of continued archival and historical work in order to challenge the primary narrative of history and also to offer an alternative perspective (or expand) that narrative. These kinds of narratives (those coming out of the gaps) are important for expansion of rhetorical conversation.

The most important function of recovery work, giving voice to marginalized populations, presents the greatest challenge when constructing narrative. In this research project, I wanted to explore rhetoric, in particular public discourse surrounding the opening of public schools for African Americans in the city of Louisville. The greatest challenge emerged from my choice to limit the study to conversations held in the public sphere. I omitted personal writing from the study in order to avoid issues of authenticity, but I did allow some letters into the study, as they were written in an official capacity to an agency or office. Nineteenth-century African-American citizens were not afforded many opportunities in public discourse, so my study had a limited presence of AfricanAmerican voices. However, what were ever present were the actions of AfricanAmerican citizens, and I used historical documentation of social, cultural, and political activity to contextualize and shape my argument.

Revisionist histories, cultural literacy narratives, and recovery narratives like this one help to shape current scholarship in the field of Rhetoric and Composition. This 
study, largely constructed from context and absence of discourse, suggests that many histories await discovery; many primary sources are yet unexplored. The nineteenth century was a period of extensive social, cultural, and political transformation--a period rich with scholarly, historical opportunities. Barbara E. L'Eplattenier likens archival work to a collage. Each recovered history represents one small picture and those smaller pictures collectively make-up the larger image. L'Eplattenier goes on to say that "We see small pictures - individuals or groups or specific moments in time- and then, stepping back and looking at many small pictures, we can see a larger picture - trends, movements, ideologies" (75). This study is one more small African-American literacy narrative to add to the larger image literacy studies.

Recovery histories are still valid, still needed, and still contribute in significant ways to the field of Rhetoric and Composition. A new generation of scholars has to continue the work completed by trailblazers in the field: James Berlin's work on the history of writing instruction, Carol Mattingly's work in the Temperance, Suffrage, and Educational Movements; Jacqueline Royster and Shirley Logan with their work in nineteenth-century, African-American women rhetors and rhetorical education; Andrea Williams and her work on African-American, self-taught literacy; Janet Cornelius and her work with literacy practices in the antebellum South. Though these scholars' contributions are tremendous, there are still many undiscovered rhetorical and literacy histories in the archives awaiting exploration. 


\section{REFERENCES}

Academic Dictionaries and Encyclopedias. http://en.academic.ru/

ALEPH. "Letter from Kentucky.” The Christian Recorder. 22 December 1866.

Anderson, Eric and Alfred A. Moss, Jr. Dangerous Donations: Northern Philanthropy and Southern Black Education, 1902-1930. Columbia: University of Missouri Press, 1999.

Bell, Derrick A. "Brown v. Board of Education and the Interest Convergence Dilemma." Harvard Law Review 93.3 (Jan. 1980): 518-533.

Berlin, James A. "Revisionary Histories of Rhetoric: Politics, Power, and Plurality." Writing Histories of Rhetoric, ed. Victor J. Vitanza. Carbondale: Southern Illinois University Press, 1993.

Blackmon, Phillip O. "Literacy, Protest, and Empowerment : $19^{\text {th- }}$ and $20^{\text {th- }}$ Century African-American Letter-Writing Rhetoric.” Diss. University of Louisville, 2010.

Brandt, Deborah. Literacy in American Lives. New York: Cambridge University Press, 2001.

---. "Sponsors of Literacy." College Composition and Communications 49.2 (1998): 165-185.

Bullock, Henry Allen. A History of Negro Education in the South: From 1619 to the Present. Cambridge: Harvard University Press, 1967.

Bullock, Penelope L. The Afro-American Press, 1838-1909. Baton Rouge, LA: Louisiana State University Press, 1981. 
Clark, Thomas D. A History of Kentucky. New York: Prentice-Hall, 1937.

---. "Public Education." The Kentucky Encyclopedia. Lexington, KY: The University Press of Kentucky, 1992.

Cornelius, Janet Duitsman. When I Can Read My Title Clear: Literacy, Slavery, and Religion in the Antebellum South. Columbia, SC: University of South Carolina Press, 1991.

“The Colored Educational Convention.” Louisville Courier-Journal. 15 July 1869. Microfilm.

Cremin, Lawrence A. American Education, the National Experience, 1783-1876. New York: Harper and Row, 1980.

Cummings, Scott and Michael Price. Race Relations in Louisville: Southern Racial Traditions and Northern Class Dynamics. Louisville, KY: University of Louisville, College of Urban and Public Affairs, Urban Research Institute, 1990.

Curry, Leonard P. The Free Black in Urban America, 1800-1850: the Shadows of the Dream. Chicago: University of Chicago Press, 1981.

Delgado, Richard and Jean Stefancic. Critical Race Theory: An Introduction. New York: New York University Press, 2001.

Doyle, Ruby Wilkins. Recalling the Record: A Documentary History of the AfricanAmerican Experience within the Louisville Public School System of Kentucky (1870-1975). Chapel Hill: Professional Press, 2005.

Dudziak, Mary L. "Desegregation as a Cold War Imperative." Stanford Law Review 41.1 (Nov. 1988): 51-120. 
Dunnigan, Alice A. The Fascinating Story of Black Kentuckians: Their Heritage and Traditions. Washington, DC: The Associated Publishers, 1982.

Ernest, John. Liberation Historiography: African American Writers and the Challenge of History, 1794-1861. Chapel Hill: University of North Carolina Press, 2004.

Foucault, Michel. “Of Other Spaces.” 1967. Trans. Jay Miskowiec. 21 January 2010. $<\underline{\text { http://foucault.info/documents/heteroTopia/foucault.heteroTopia.en.html }>\text {. }}$

Gilyard, Keith. "African Americans Contributions to Composition Studies." CCC 50.4 (June 1999): 626-644.

Graff, Harvey J. The Literacy Myth: Cultural Integration and Social Structure in the Nineteenth Century. New Brunswick, NJ: Academic Press, Inc., 1991.

Horner, Bruce and Min Zahn Lu. Representing the "Other" : Basic Writers and the Teaching of Basic Writing. Urbana, IL: National Council of Teachers of English, 1999.

Howard, Victor. Black Liberation in Kentucky: Emancipation and Freedom, 1862-1884. Lexington, KY: the University Press of Kentucky, 1983.

Hudson, James Blaine. Fugitive Slaves and the Underground Railroad in the Kentucky Borderland. Jefferson, N.C.: McFarland and Company, 2002.

--.. "The Establishment of Louisville Municipal College: A Case Study in Racial Conflict and Compromise." The Journal of Negro Education. 64.2 (Spring 1995): $111-123$

---. "The History of Louisville Municipal College: Events Leading to the Desegregation of the University of Louisville.” Diss. University of Kentucky, 1981. 
---. Personal Interview. 22 September 2009.

Johnson, Nan. Gender and Rhetorical Space in American Life, 1866-1910. Carbondale, IL: Southern Illinois University Press, 2002.

Kentucky State. Bureau of Refugees, Freedmen, and Abandoned Land. Seventh SemiAnnual Report on Schools dated January 1868. Kentucky: Louisville, 1868.

---. Colored Educational Convention. Proceedings. 14 July 1869 . Western Kentucky University Archives.

---. Superintendent of Education Annual Report to Governor of the State of Kentucky 1868, 1869, 1870-71, 1872. Collected Documents. Kentucky State Archives.

Kliebard, Herbert M. The Struggle for the American Curriculum, 1893-1958. New York: Routledge \& Kegan Paul, 1987.

L’Eplattenier, Barbara E. “Opinion: An Argument for Archival Research Methods: Thinking Beyond Methodology." College English 72.1 (Sept 2009): 67-79.

"Local Evils." Louisville Public Advertiser. 30 November 1835. Microfilm. University of Louisville Library.

Logan, Shirley Wilson. “We Are Coming." Carbondale: Southern Illinois University Press, 1999.

---. With Pen and Voice. Carbondale: Southern Illinois University Press, 1995.

Louisville, Kentucky. School Board Meetings. Minutes. 4 April 1870. University of Louisville Archives. Louisville, Kentucky.

Lu, Min Zahn and Bruce Horner. Writing Conventions. New York: Pearson Longman, 2008. 
Lucas, Marion B. A History of Blacks in Kentucky. vol. 1. The Kentucky Historical Society, 1992.

Mattingly, Carol. "Telling Evidence: Rethinking What Counts in Rhetoric." Rhetoric Society Quarterly. 32.1 (Winter 2002): 99-108.

McAfee, Ward M. Religion, Race, and Reconstruction: The Public School in the Politics of the 1870s. Albany: State University of New York Press, 1998.

McDougle, Ivan E. Slavery in Kentucky 1792-1865. Lancaster, PA: Press of the New Era Printing Company, 1918.

Monaghan, E. Jennifer. Learning to Read and Write in Colonial America. Amherst: University of Massachusetts Press, 2005.

Mountford, Roxanne. The Gendered Pulpit: Preaching in American Protestant Spaces. Carbondale, IL: Southern Illinois University Press, 2003.

Nasaw, David. Schooled to Order: A Social History of Public Schooling in the United States. Oxford: Oxford University Press, 1979.

Ramsdale, J. B. Letter to General O. O. Howard. 22 January 1868. Freedmen Bureau Papers. National Archives. Washington, D.C.

Reynolds, Nedra. Geographies of Writing: Inhabiting Places and Encountering Difference. Carbondale, IL: Southern Illinois University Press, 2004.

Richardson, Elaine B. African American Literacies. New York : Routledge, 2003.

Royster, Jacqueline Jones. Traces of a Stream. Pittsburgh: University of Pittsburg Press, 2000.

--- and Jean Williams. "History in the Spaces Left: African Americans Presence and Narratives of Composition Studies.” 1999 CCC 50.4 (June 1999): 563-584. 
[Royster] Jones, Jacqueline. Soldiers of Light and Love: Northern Teachers and Georgia Blacks. Chapel Hill: University of North Carolina Press, 1980.

Schein, Richard H. "The Place of Landscape: A Conceptual Framework for Interpreting an American Scene." Annals of the Association of American Geographers 87.4 (Dec 1997): 660-680.

Simmons, Charles A. The African American Press: A History of Coverage During National Crises, with Special Reference to Four Black Newspapers, 1827-1965. Jefferson, N.C.: McFarland and Company, Inc., 1998.

Smitherman, Geneva. Talkin and Testifyin : The Language of Black America. Boston: Houghton Mifflin, 1977.

---. Black Talk: Words and Phrases from the Hood to the Amen Corner. Boston: Houghton Mifflin, 1994.

Strothers, T. "Letter from Louisville.” The Christian Recorder. 3 June 1865. United States of America. Census. 1850: 612.

-... -... 1860: 182.

-.-. -... 1870: 150.

---. Consolidated School Report to Bureau of Refugees, Freedmen, and Abandoned Land for the Six Months Ending January 1, 1869. Washington, D.C.: 1869.

Vaughn, William Preston. Schools for All: The Blacks and Public Education in the South, 1865-1877. Lexington: University of Kentucky Press, 1974.

Venable, Tom C. "A History of Negro Education in Kentucky." Diss. George Peabody College for Teachers, Nashville, TN, 1952. 
Weeden, Henry C. Weeden's History of Colored People of Louisville. Louisville, KY: Juanita Landers White, 1986.

West, Earle H. The Black American and Education. Columbus, OH: Bell \& Howell Company, 1972.

Williams, Heather Andrea. Self-taught: African American Education in Slavery and Freedom. Chapel Hill: University of North Carolina Press, 2005.

Wilson, George D. A Century of Negro Education in Louisville, Kentucky. revised edition. Louisville, KY: Louisville Municipal College, 1941/1986.

Woodson, Carter G. Education of the Negro Prior to 1861. Charleston, S.C.: Bibliobazaar, 2007 (original 1919).

Wright, George C. Life Behind a Veil: Blacks in Louisville, Ketnucky, 1865-1930. Baton Rouge: Louisiana State University Press, 1985.

Yater, George H. Two Hundred Years at the Falls of the Ohio: a History of Louisville and Jefferson County. Louisville, KY: The Heritage Corporation of Louisville and Jefferson County: distributed by the Filson Club, 1979. 


\section{Appendix 1}

An Act for the Benefit of the Negroes and Mulattos in this Commonwealth: 1866

Be it enacted by the General Assembly of the Commonwealth of Kentucky:

1. In addition to the tax already levied by the laws of this commonwealth, a tax of two dollars shall be levied on every male Negro and mulatto over the age of eighteen years, to be assessed and collected as other taxes, and when paid into the Treasury, shall go into the fund aforesaid.

2. The commissioner of taxes in each county shall keep a separate book, or a separate column in his books for the enlistment of the taxable property of Negroes and mulattos, and in which the names of all the male Negroes and mulattos over the age of eighteen shall be recorded.

3. The trustees of each school district in this Commonwealth may cause a separate school to be taught in their district for the education of the Negro and mulatto children in said district, to be conducted and reported as other schools are, upon which they shall receive their proportion of the fund set apart in this act for that purpose.

4. The county court of each county may certify to the Auditor of Public Accounts the number of Negro and mulatto paupers kept in each county, and upon such certificate draw their proportion of the fund set apart in this act for that purpose. Said reports shall be made by said courts at their annual court of claims.

5. Chapter 88 of the Revised Statutes, and amendments thereto, shall regulate the mode and manner of distributing the school fund realized under this act; but no part of said fund shall ever be drawn or appropriated otherwise than pursuant to this act in aid of common schools for Negroes and mulattos.

6. The Auditor shall apportion each year the revenue from the fund realized under this act for the benefit of said paupers among several counties of the State according to the number of said paupers in each county, as shown by the reports of the several county courts.

7. Nothing in this act shall be construed as interfering with the rights of the county courts in levying county taxes. This act shall take effect from passage.

Approved: February 16, 1866 (Doyle 51) 


\section{Appendix 2}

\section{An Act for the Benefit of the Negroes and Mulattos of this Commonwealth: 1867}

Be it enacted by the General Assembly of the Commonwealth of Kentucky:

1. That the capitation and other taxes collected from Negroes and mulattos shall be set apart and constitute a separate fund for the support of their paupers and the education of their children, as hereinafter provided.

2. In addition to the capitation tax already levied by the laws of this Commonwealth, a tax of two dollars shall be levied on every male Negro and mulatto over the age eighteen years, which shall be assessed and collected as other taxes, and go into the fund aforesaid.

3. The commissioner of taxes in each county shall keep a separate column in his book for the enlistment of taxable property of Negroes and mulattos, and in which the names of all male Negroes and mulattos over the age of eighteen years shall be recorded.

4. The taxes collected under this act shall be applied exclusively to the support of the Negro and mulatto paupers, and the education of Negro and mulatto children in the county in which it was collected.

5. The sheriff shall pay over said fund to the county treasurer; and if there be no county treasurer, it shall be the duty of the annual court of claims to elect, every two years, a receiver, to whom the sheriff shall pay the fund aforesaid. The receiver shall execute bond, with good security, approved by the presiding judge, for the faithful performance of his duties. The county treasurer, or receiver, shall hold said fund subject to the order of the annual court of claims.

6. The trustees of each common school district in the county may cause a school to be taught in their district for the education of Negro and mulatto children in said district; and shall report to the county school commissioner the number of children in attendance at said school during the year, for not less than three months; and the county school commissioner shall report to the annual court of claims all the Negro schools thus taught in the county ; and said court shall allow, out of the fund aforesaid, two dollars and fifty cents $(\$ 2.50)$ for each scholar who has attended school three months, or a longer period. The county judge, when said appropriation is made, shall draw his warrant on the county treasurer, or receiver, in favor of the county school commissioner, for the aggregate amount thereof; and the county school commissioner shall pay the same proportionately to the trustees of each school district, to be applied by them in defraying the expenses of the said school for the year. The county school commissioner shall report annually to the Superintendent of Public Instruction the number of Negro 
schools taught, number of children in attendance, and amount paid by him under this act. The county commissioners shall be responsible, on his official bond, for the school fund that passes into his hands. The court may allow him a reasonable sum for his services, as aforesaid, to be paid out of the fund. No person shall be a teacher under this act, unless he has first obtained a certificate from the county commissioner, certifying that he is qualified, and is a proper person to teach the schools herein provided for.

7. The residue of said fund shall constitute the Negro and mulatto pauper fund of the county. It shall be the duty of the county court to provide for the taking care of the Negro and mulatto paupers in the county. It shall be the duty of the court of claims to audit the claims of such persons in the county who have taken care of and provided for Negro or mulatto paupers, under the order of the county judge; and, when a claim is allowed, the court shall authorize the presiding judge to draw his warrant on the county treasurer, or receiver, in favor of the claimant, for the amount thereof.

8. It shall be the duty of the sheriff of each county to notify anyone who is indented to a Negro or mulatto the amount of his taxes under this act, that he will subject the amount thereof to the payment of said tax; whereupon, it shall be the duty of the debtor to pay, when due, the amount of said Negro's taxes to the sheriff, and the payment by the debtor shall be a discharge of so much of the indebtedness.

9. An act, entitled "An Act for the Benefit of the Negroes and Mulattos of This Commonwealth," approved February 16, 1866, is hereby repealed.

10. The funds collected from each county and paid into the Treasury under said act, shall be drawn from the Treasury by the county court of the county in which they were collected, to be disposed of by said court under the provisions of this act.

11. This act to take effect from its passage.

Approved March 9, 1867 (Doyle 52-55) 


\title{
Appendix 3
}

\section{An Act To Amend 'An Act for the Benefit of the Negroes and Mulattos of This Commonwealth'}

\author{
Approved March 9, 1867.
}

Whereas: A difference of opinion exists in regard to the application of a fund authorized to be raised by an act, entitled "An act for the Benefit of the Negroes and Mulattos of this Commonwealth," approved March $9^{\text {th }}, 1867$ :

Be it enacted by the General Assembly of the Commonwealth of Kentucky:

1. That no part of the fund authorized to be raised by the aforesaid act shall be applied to school purposes as therein provided, except whatever excess there may be after providing for the Negro and mulatto paupers in each county.

2. No part of said fund collected in the present year shall be applied, except as provided in the first section of this act.

3. This act shall be in force from its passage.

Approved January 9, 1868 (Doyle 60) 


\section{CURRICULUM VITAE}

\section{Michelle Bachelor Robinson}

2507 Wyeth Court

Louisville, KY 40220

(502) 290-0338

mrbach01@1ouisville.edu
University of Louisville

English Department and

Undergraduate Affairs

Strickler Hall \#230

Louisville, KY 40292

(502) 852-7865

\section{Education}

Ph.D. Rhetoric and Composition, University of Louisville, May 2010

Dissertation Topic: "'Still I Rise!' Public Discourse Surrounding the

Development of Public Schools for African Americans in Louisville, Kentucky 1862-1872."

My dissertation is an archival project in which I gathered local, state, and national historical artifacts that give an account of the struggle for public education by African Americans in the city of Louisville, KY. Citing Deborah Brandt's "Sponsors of Literacy" as a conceptual framework and Jacqueline Royster's Soldiers of Light and Love as a precedent, I argue that African-American Louisvillians assert agency through several social and political mediums to achieve literacy for the purpose of social and economic upward mobility. This project historicizes the pursuit of literacy for African Americans and explores issues of race relations, as the agency asserted by the African-American community is more clearly defined by the resistance of the white majority. I further complicate the discussion of African Americans' literacy by offering Louisville as a historic case study for how an established and empowered community of free blacks can serve as a catalyst to bring about social change beyond the immediate sphere.

Committee: J. Carol Mattingly (Chair), J. Blaine Hudson, David Anderson, Susan Ryan, and Dennis Hall

M.A. English, University of Louisville, May 2005 
B.A. English, Cameron University, May 1994

Minor: History and Secondary Education Certification

A.A. Business Management, Western Kentucky University, May 1989

\section{Conference Presentations}

"Life, Liberty, and the Pursuit of Literacy: Remixing Definitions of Agency for AfricanAmericans in $19^{\text {th }}$ Century Louisville, Kentucky." Conference on College Composition and Communication, Louisville, KY. March 2010.

"Community Dynamics in the Construction of Race: African-Americans in Louisville, Kentucky Pre and Post Emancipation.” 2009 Diversity Research Symposium, Ball State University. Muncie, Indiana. November 2009.

"Can I Find My Face in this Place? The Evolution from African-American Graduate Student to Scholar." Conference on College Composition and Communication. San Francisco. March 2009.

"Considering Successful Models of Mentorship for Upcoming Scholars of Color." Poster Presentation, Scholars for the Dream Reception, Conference on College Composition and Communication. San Francisco. March 2009.

"A Two-Edged Sword: The Rhetoric Surrounding the Development of Public Schools for African Americans in Louisville, Kentucky." South Atlantic Modern Language Association Conference. Louisville. November 2008.

"A Positive Charge in the So-Called Neutral Zone: Discovering Two Women with One Great Task." Feminism(s) and Rhetoric(s). Little Rock. October 2007.

"The Printed Veil: Tensions Among the Written and the Unwritten in the HBO series Big Love." Pop Culture Association in the South and American Culture Association in the South. Boston. April 2007.

" $19^{\text {th }}$ Century Literacy Practices of African Americans." Kentucky Conference on Reading. Louisville. September 2006.

"Renegotiation of Race in Shakespeare's Othello." Kentucky Philological Association, Northern Kentucky University, Highland Heights. April 2005.

\section{Invited Presentations}

"From Historical Enthusiast to Scholar: My Journey through Louisville's History of African-American Literacy." Black Faculty and Staff Association, University of Louisville, Louisville, KY. January 2010. 
"Finding Zora: How I Met Zora Neale Hurston and What She Told Me About

Their Eyes. . " The National Endowment for the Arts: The Big Read. Shively Public Library. Louisville, KY. September 2007.

\section{Administrative Experience}

College Conference on Composition and Communication, Local Chair. March 2009present. Serve as liaison between the National Council for Teachers of English (NCTE) and local entities in every aspect of planning: facility, registration, events, and exhibits. Serve as the local representative of the national body with local entities in final arrangements. Coordinate volunteer service for the duration of the meeting. Responsible for creating a unique and local flair for the conference.

General Education Curriculum Assessment Coordinator, University of Louisville, May 2005-present. Coordinate cross-disciplinary assessment of all courses listed in General Education curriculum. Conduct reader training for faculty and graduate assistants in assessment technique and rubric usage.

\section{Teaching Experience}

Graduate Teaching Assistant, University of Louisville, 2004-2005, 2008-Present Introduction to College Writing (English 101)

Intermediate College Writing (English 102)

Business Writing (English 306)

African American Literature 1845 to Present (English 323)

Writing Center Consultant, University of Louisville, August 2003-May 2004.

Assisted undergraduate and graduate students in all disciplines with academic, professional, and personal writing in one-on-one tutoring sessions and in specialized workshops: helped students develop effective strategies for time management, reading, note-taking, and test-taking.

\section{Secondary Instruction}

Lincoln Park Academy, Classroom Teacher Fort Pierce, FL February 2000 - June 2003 Provided academic instruction for Debate I-IV, Drama I-IV, and English I-IV, prepared at-risk students for statewide writing and reading assessment, and served on county-wide textbook adoption committee.

Central High School, Classroom Teacher, Fort Pierce, FL August 1994 - June 1999 Provided academic instruction for English I-IV, taught and developed curriculum for Teacher Assistant Elective and Study Skills courses, as well as prepared atrisk students for statewide writing and reading assessment, and served on county-wide behavior policy task force. 


\section{Grants, Awards, and Honors}

Most Creative Content Award for Presentation, 2009 Diversity Research Symposium, Ball State University. Muncie, Indiana. November 2009, \$200.

Signature Partnership Initiative Grant for Graduate Students (SPIGGS), University of Louisville, funding of graduate student research projects with populations in the West Louisville area, a predominantly African-American community, $\$ 1,000$. 2009.

Scholars for the Dream, Conference on College Composition and Communication, $\$ 750$, 2009.

Bonnie Fund Dissertation Travel Award, English Department, University of Louisville, $\$ 400,2009$.

Doctoral Scholars Fellowship, Southern Region Educational Board, 2005-2008.

University of Louisville Minority Graduate Fellowship, 2003-2004.

Outstanding Minority Educator, Lincoln Park Academy, St. Lucie County, Florida, 2003.

\section{Leadership and Service}

College Conference on Composition and Communication 2010, Stage II

Reviewer. June 2009. Selected by program chair to assemble at NCTE in Urbana, Illinois, to review CCCC 2010 conference proposals, and to create panels from selected proposals.

General Education Curriculum Committee, University of Louisville, August 2005present. Oversee the implementation of the University-Wide General Education Program and review and study the overall program and the courses offered within, write guidelines and set policies for the submission and approval of courses for the General Education Program, develop, oversee implementation of, and review assessment measures, and change the General Education Program as needed for continuous improvement or as mandated by changes to University, $\mathrm{CPE}$, or SACS requirements.

General Education Assessment Rubric Development Committee, University of Louisville, August 2005-present. Drafted rubrics to measure critical thinking, effective communication, and cultural diversity in multiple disciplines. 
Degree Verification Committee, University of Louisville. September 2008.

Gathered and analyzed data of current degree verification practices in the various colleges within the university and made recommendations to the provost for a standardized policy and practice.

National Conference on Graduate Student Leadership Planning Committee. March 2007. Worked jointly with the University of Kentucky, University of Louisville, Washington University in St. Louis, the Kentucky Council on Postsecondary Education, and the Woodrow Wilson Foundation in planning a conference that prepares graduate students for leadership roles on campus, in the community, and in their future professions.

College of Education Search Committee. University of Louisville. October 2006.

Served as a member of the Literacy Search Committee, Department of Teaching and Learning.

\section{Professional Memberships}

College Composition and Communication, 2006-2009

Black Caucus, College Composition and Communication, 2006-2009

Coalition of Women Scholars, 2006-2009

National Council of Teachers of English, 2008-2009

Modern Language Association, 2008-2009

South Atlantic Modern Language Association, 2008-2009

Pop Culture Association / American Culture Association, 2006-2007

Kentucky Philological Association, 2004-2005

\section{Selected Graduate Courses}

\section{Pedagogy}

Writing Center Theory and Practice (J. Carol Mattingly)

Teaching Composition (Bronwyn T. Williams)

Study of Professional Writing (Geoffrey Cross)

Teaching Literature (Beth Boehm)

\section{Research and Technology}

Digital Composing (Debra Journet)

Research Methods (Debra Journet)

Applied Statistics (Edward "Skip" Kifer)

\section{Rhetoric and Theory}

History of Rhetoric (Carol Mattingly)

Perspectives on Literacy (Deborah Brandt-Watson Professor)

Basic Writing Theory and Scholarship (Bruce Horner) 
Narrative Theory (Debra Journet)

Contemporary Theories of Interpretation: Feminist and Marxist (Marc Bousquet)

Post-Modernism (Tom Byers)

Curriculum Theory (Ann Larson)

\section{Literature}

African American Narratives of the Urban Experience (Karen Chandler)

Black Print and Oral Cultures (Karen Chandler)

Fantastic Metamorphosis: Narratives of Transformation (Susan Griffin)

$19^{\text {th }}$ Century British Poetry and Prose (Mary Rosner)

Victorian Afterlife: Postmodern Rereading of the $19^{\text {th }}$ Century (Beth Boehm)

Study of American Literature to 1865 (Susan Ryan)

Shakespeare (Julia Deitrich)

\section{Other Coursework}

Educational Leadership Coursework, Florida Atlantic University, 2001

Advanced Technology Training, Indian River College, 1998-2000

Early Childhood Education Coursework, Indian River College, 1998-2000

\section{Extra-Curricular Academic Involvement}

English Graduate Organization (EGO)

EGO PhD Representative for

English Department Faculty Meetings

Watson Conference Volunteer

University of Louisville $20^{\text {th }}$ Century

Literature Conference Volunteer

Lincoln Park Academy

Martin Luther King

Commemorative Committee

Site Coordinator

Lincoln Park Academy Theater Director

Lincoln Park Academy

Balanced Reading Coordinator

Lincoln Park Academy

Debate Team Coach

Fort Pierce Central Zora Neale Hurston

Biographical Film Research Team, Script Writer, and Actress

Fort Pierce Central Cheerleading Sponsor

Fort Pierce Central Disciplined Based

Arts Education Committee
August 2004—Present

August 2009-Present

2004, 2006, 2008

2004, 2005, 2006

2002-2003

2000-2003

2001-2002

2000-2002

1998-1999

1997-1998

1996-1999 
Fort Pierce Central

Technology Committee

1995-1999

Fort Pierce Central Future Educators of America Sponsor

1996-1999

\section{Community Involvement}

The Louisville CHUMS

Women's Social and Civic Club

2008-present

Woodmen of the World Lodge \#53

Vice President \& Musician

1996-2003

Zora Neale Hurston Historical Committee

Fort Pierce, Florida

2000-2003

Martin Luther King Community

Commemorative Committee

Fort Pierce, Florida

1996-2003

NAACP

1995-2003

Fort Pierce Jaycees

1995-2000 